Portland State University

PDXScholar

12-13-1973

\title{
A Preliminary Investigation of the Land Use Limitations of the Major Landforms Along a Portion of the Lincoln County Coast, Oregon
}

Richard Kent Mathiot

Portland State University

Follow this and additional works at: https://pdxscholar.library.pdx.edu/open_access_etds

Part of the Geology Commons

Let us know how access to this document benefits you.

Recommended Citation

Mathiot, Richard Kent, "A Preliminary Investigation of the Land Use Limitations of the Major Landforms Along a Portion of the Lincoln County Coast, Oregon" (1973). Dissertations and Theses. Paper 2170. https://doi.org/10.15760/etd.2166

This Thesis is brought to you for free and open access. It has been accepted for inclusion in Dissertations and Theses by an authorized administrator of PDXScholar. Please contact us if we can make this document more accessible: pdxscholar@pdx.edu. 
AN ABSTRACT OF THE THESIS OF Richard Kent Mathiot for the Master of Science in Geology presented December 13, 1973.

Title: A Preliminary Investigation of the Land Use Limitations of the Major Landforms Along A Portion of the Lincoln County Coast, Oregon.

APPROVED By MEMBERS OF THE THESIS comitTeE:

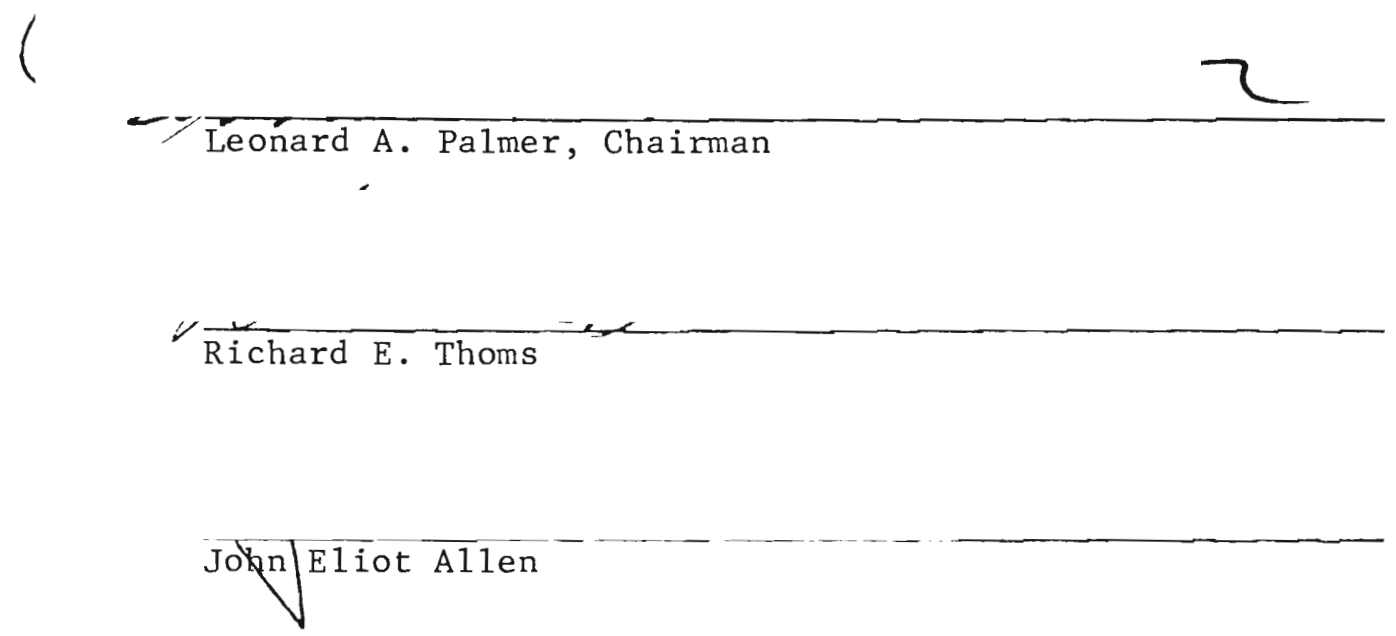

\section{Ear1 R. Rosenwinke1}

Charles G. Davis

This study of a portion of Oregon's Lincoln County coast describes the physical limitations to land use of the various landforms in the study area. Seven major landform types comprise the study area: beaches, active dunes, stabilized dunes, marsh land and tidal flats, marine terraces, basaltic headlands, and uplands. Descriptions and evaluations 
TO THE OFFICE OF GRADUATE STUDIES AND RESEARCH:

The members of the Committee approve the thesis of

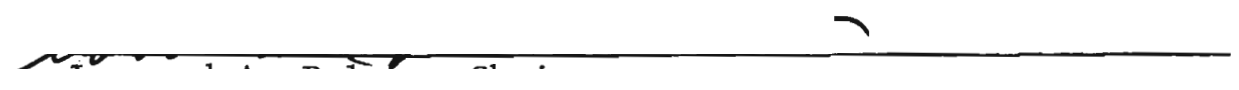

$\checkmark$ Richard E. Thoms, Chairman, Department of Earth $\overline{\text { Science }}$

Jobn Eliot Allen

Ear1 R. Rosenwinke1

Charles G. Davis

APPROVED :

Davíd T. Clark, Dean of Graduate Studies and Research 
TABLE OF CONTENTS

PAGE

LIST OF TABLES . . . . . . . . . . . . . . . . . v v LIST OF FIGURES . . . . . . . . . . . . . . . . . vi vi CHAPTER

I INTRODUCTION ................... 1

II MAJOR LANDFORMS ................ 11

Beaches ............... 12

Active Dunes ............. . 13

Stabilized Dunes ............ 14

Marsh Lands and Tidal Flats . . . . . . 15

Marine Terraces . . . . . . . . . 17

Basaltic Headlands . . . . . . . . 18

Uplands . . . . . . . . . . . . 19

III GEOLOGIC HISTORY . . . . . . . . . . . . . 27

IV GEOLOGIC AND ENGINEERING CHARACTERISTICS

OF THE MAJOR LANDFORM TYPES . . . . . . . 36

V GEOLOGIC PROCESSES OF POTENTIAL HAZARD TO MAN . . . 45

VI SUITABILITY FOR RESIDENTIAL OR LIGHT-COMMERCIAL

DEVELOPMENT ................ 55

VII SUMMARY AND RECOMMENDATIONS ............. 62

BIBLIOGRAPHY ... . . . . . . . . . . . . . 63 
PAGE

APPENDIX A . . . . . . . . . . . . . . . . 66

APPENDIX B . . . . . . . . . . . . . . . . . 78 


\section{LIST OF TABLES}

TABLE

PAGE

I Soil Series Characteristics Pertinent

to Land Use Planning . . . . . . . . . . . 77

II Shoreline Erosion Rates - Test Descriptions and Results . . . . . . . . . . . 83 


\section{LIST OF FIGURES}

FIGURE

PAGE

1 Study area location map . . . . . . . . . . . 2

2 Population trends in and around the study area . . . . 4

3 Generalized marine terrace features . . . . . . . 17

4 Four landform relationships common to the study area. . 22

5 Broad sand beach - 2 miles north of Fishing Rock . . 23

6 Marsh lands and tidal flats on the southeast side of Siletz Bay ............... 23

7 Active dunes - view is looking south across mouth of Yaquina Bay............... . . 24

8 Marine terraces near Otter Rock - view is southward from Otter Crest State Park . . . . . . . 24

9 Stabilized dunes with sea-grass and localized forest cover - view is southward along the spit at Alsea Bay . . . . . . . . . . . . .

10 Basaltic headland of Otter Crest - view is southward from Cape Foulweather .......... 25

11 Uplands on eastera edge of Yaquina Bay . . . . . . 26

12 Stratigraphic column . . . . . . . . . . 28

13 Erosion of beach sand at Salishan Spit - damage to man made structures resulted from erosion of over 75 feet of material along portions of the spit in January, 1973 . . . . . . . . . . . . 
14 Condominium units constructed around the mouth

of Little Creek despite numerous potentially hazardous conditions . . . . . . . . . 52

15 Erosion of marine terrace materials exposed in the sea cliff near Moloch Beach, 1.5 miles north of Yaquina Head . . . . . . . . . . . . 53

16 Landslide scarp resulting from failure of marine terrace materials and dipping Astoria Formation one mile south of Otter Rock Highway 101, right side of photo, was damaged by this slide and required repaving . . . . .

17 Terrace sea-cliff landslide at Jump off Joe, one half mile north of Newport . . . . . . . 54

18 Population pressures are resulting in increased development in the potentially hazardous foothills of the upland areas ........... . . 54

19 Slope evaluation map - evaluation map 非 1 . . . . . 57

20 Solls evaluation map - evaluation map 非 . . . . . 59

21 Geologic hazards evaluation map - evaluation map \#3 • . 60

22 Soil horizon diagram . . . . . . . . . . 67

23 Unified Soil Classification System - soil texture chart ................. 69

24 Erosion rate test results - unconsolidated marine terrace materials . . . . . . . . . 82 
25 Erosion rate test results - tertiary sedimentary rocks........... 82

26 Suitability for residential or light commercial

development - evaluation summary map . . . map pocket

27 Soil series map . . . . . . . . . . map pocket

28 Major landforms and associated rock types - with erosion station localities . . . . . map pocket 
CHAPTER I

\section{INTRODUCTION}

Oregon's coastline, one of the most beautiful and accessible to be found anywhere, is an environment threatened by mismanagement. The desire to use or own a portion of this environment has resulted in a tremendous increase in the seasonal or semi-permanent population along the coast. Real estate firms, builders, and other business concerns have responded to this increase with the construction of condominiums and summer homes, the subdivision of acreage, and the establishment of various convenience facilities. This rapid influx is threatening to upset the balanced equilibrium of the coastal environment, and thereby destroy those same natural qualities which make the area so desirable. An understanding of the geologic conditions of the coastal region, and in particular the study area, can provide methods whereby the despoiling of this unique environment may be prevented.

In his book, Design With Nature, Ian McHarg (1971) demonstrates that the greatest problem facing the environmentalist is man's "anthropocentric interpretation of the natural environment" that has been instilled in his cultural heritage through the past few generations. The present study attempts to provide the basis for a better understanding of the landforms, geologic processes, rock and soil types, and the geologic hazards of the coastal area in order that man can learn how to best live with these natural conditions rather than attempt to blindly 
dominate them.

\section{STUDY AREA DESCRIPTION}

The study area includes a $37 \mathrm{mile}(59.6 \mathrm{~km})$ strip of 1 and between Highway 101 and the western edge of the active beach zone, as well as lands surrounding three main estuaries: Siletz Bay, Yaquina Bay, and Alsea Bay. The northern boundary is the north end of Siletz Bay, and the southern boundary is approximately one mile $(1.6 \mathrm{~km})$ south of the city of Waldport (see Fig. 1). The region defined by these boundaries is an area of high population impact and developmental pressure.

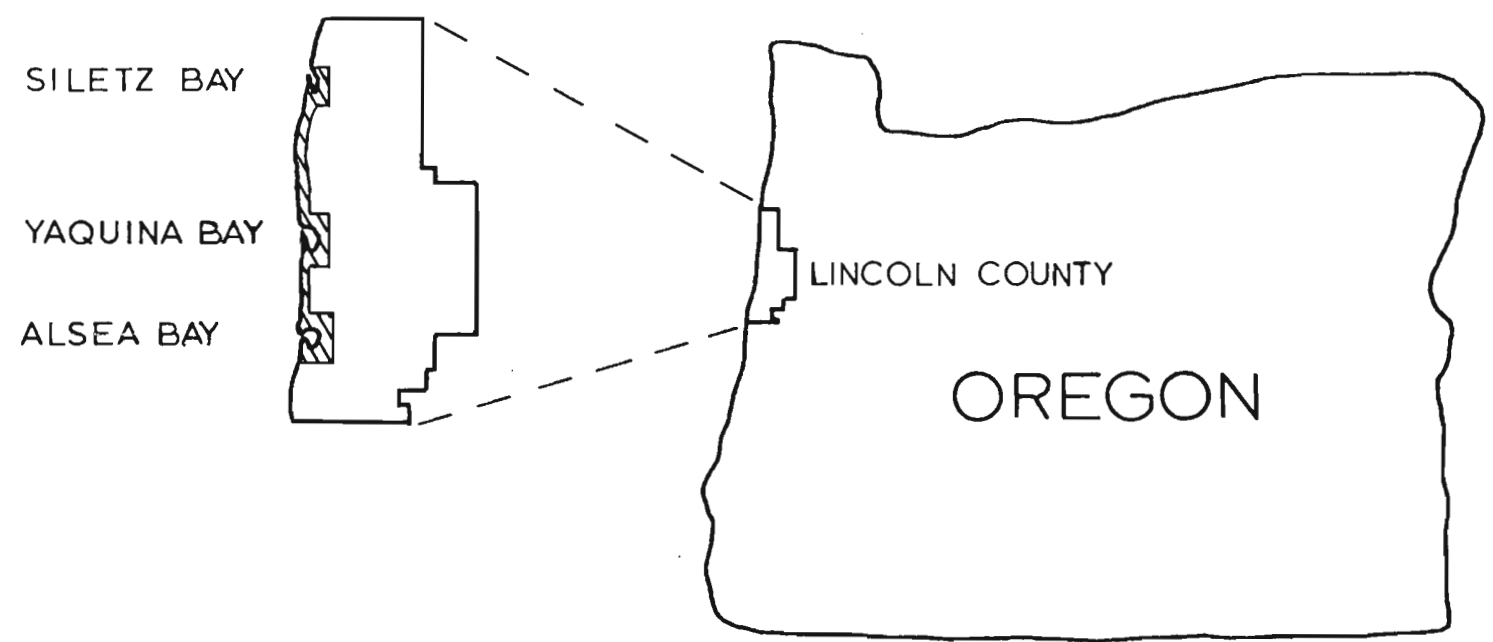

Figure 1. Study area location map.

\section{Population}

Population centers in the area are: Taft, Gleneden Beach, Lincoln 
Beach, Depoe Bay, Otter Rock, Agate Beach, Newport, South Beach, and Waldport. The three main population centers - Taft, Newport, and Waldport - are adjacent to the three estuaries of Siletz Bay, Yaquina Bay, and Alsea Bay respectively. Population increases two to eight times during the summer and early fall months when vacationing tourists and summer residents utilize the campgrounds, motels, summer cabins, and condominiums located throughout the study area. Both permanent and visitor populations have been increasing, in some cases rapidly, over the past four years. Fig. 2 is a graph showing various population trends in or near the study area.

\section{$\underline{\text { Economic Base }}$}

The area's economy is supported primarily by timber industries, tourism, and commercial fishing. A11 three of these industries are directly related to natural environmental resources of the area, and depend on resource conservation for continuing success.

\section{PURPOSE OF THE STUDY}

This study defines the physical characteristics of the 1 and and their relation to, and interaction with, man's cultural development. Geological factors such as landforms, rock types, soils, and natural processes are described and evaluated to define their limitations to 1 and use. This information is absolutely necessary if we are to preserve those qualities that make the coastal area so desirable; and to protect development from problems such as landslides, flooding, wave erosion, and failure of septic drain-field systems.

The most pressing problem facing the users of the coastal environ- 


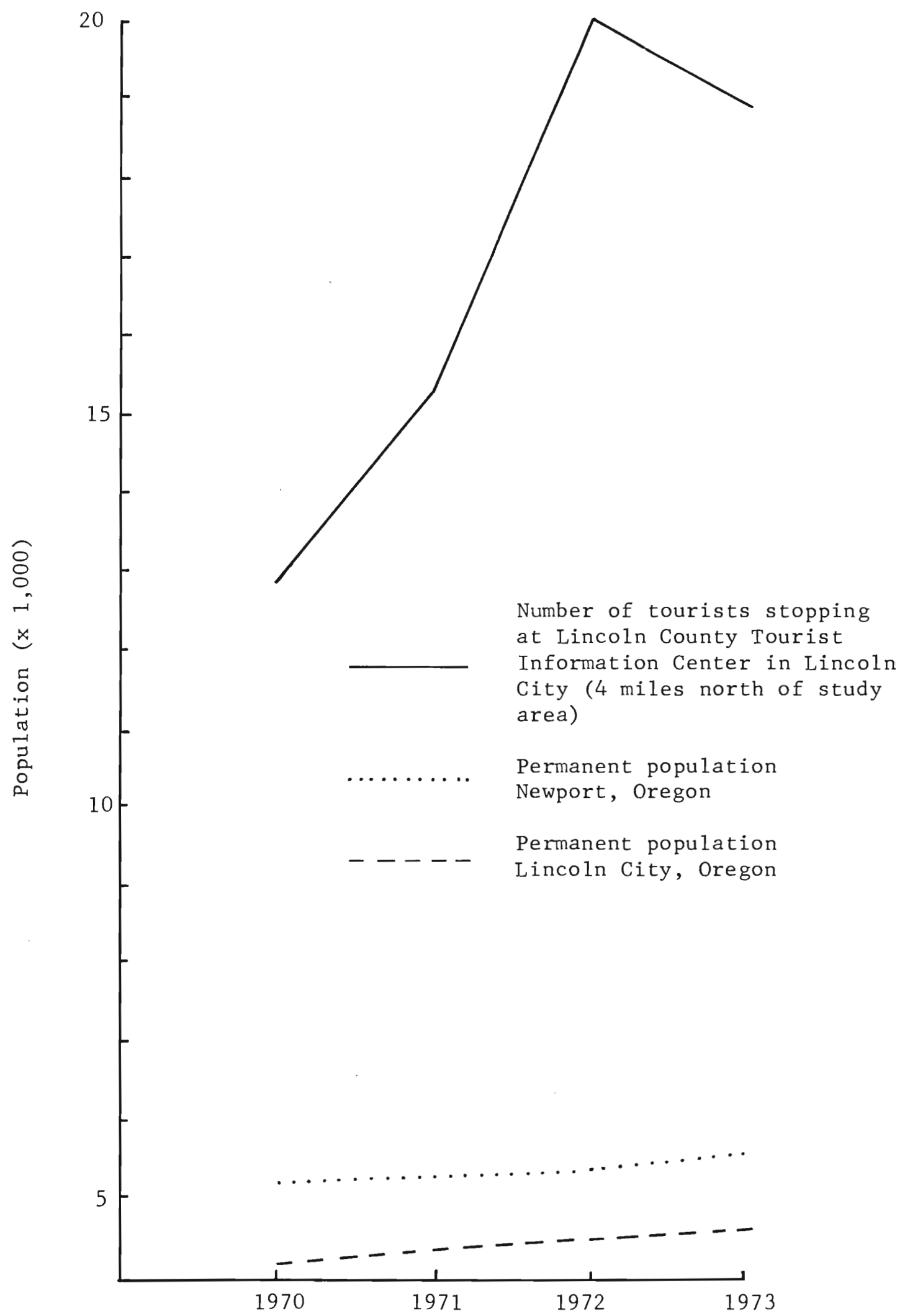

Figure 2. Population trends in and around the study area. 
ment is the need for adequate land use planning in order to enable thoughtful accommodation of the transient and permanent population increase. Current approaches to the planning problem lack detailed definitions of the environmental parameters involved. The geologic conditions of the area are used herein to develop a "base map" for land use planning. This report delineates landforms, rock units, soil series, and hazards in a way that gives a foundation for laying out an adequate land use system. It can then be used in conjunction with descriptions of other environmental parameters, such as biology, meteorology, economics, etc. in order to develop a more complete working plan.

\section{THE PLAN}

This study was executed in three phases. The first phase involved the gathering of available information on the study area, or related to the basic problem. Published data were collected on geological history, stratigraphic units, structure, physical and cultural geography, hydrology and ground water, and coastal processes, and were evaluated to define characteristics and limitations such as: stability, erosion rates, soil types, hydrologic characteristics, and engineering qualities of various materials in the study area.

The second phase involved the collection of new information to update and supplement the existing data. This included the collection of the most recent unpublished or open file information on soils (Lincoln County Soil Conservation Service), and bedrock geology (Snavely, 1972), and mapping of surficial geology and stability problems. A series of sea-cliff erosion-rate stations, believed to be the first 
of their kind in Oregon, were established and periodically monitored during this phase.

The third phase was the compilation of the new and existing information from phases one and two to evaluate land use limitations, and the presentation of that information. The information is presented in the text, and in the accompanying maps. The report is designed so that the maps (Figures 19, 20,21, 26, 27, 28) can be used separately or in conjunction with the more detailed, supplementary information contained in the appendices and text.

\section{CLTMATE AND VEGETATION}

Many 1 and-use problems in the study area are a result of climatic conditions. High annual rainfal1 [from 50" $(127 \mathrm{~cm})$ on the coast to over 100" (254 cm) in the upland areas] promotes slope instability, flooding, and rapid erosion. Nearly constant winds [commonly from 10 to $30 \mathrm{mph}(16.1$ to $48.3 \mathrm{~km} / \mathrm{hr})]$, erode and transport beach and dune sands causing constant shifting of these unconsolidated materials. In addition, the combination of constant winds and the presence of unconsolidated sand deposits results in a natural, and potentially damaging, sand-blasting effect on landforms, vegetation, and man-made structures.

Temperatures, stabilized by marine influence, have an average range of $18^{\circ} \mathrm{F}-10^{\circ} \mathrm{C}-\left[\right.$ from $50^{\circ} \mathrm{F}\left(10^{\circ} \mathrm{C}\right)$ in December to $68^{\circ} \mathrm{F}\left(20^{\circ} \mathrm{C}\right)$ in $\mathrm{July}$; Bureau of Govt. Research, 1969 ], and allow outdoor activity throughout the year.

There is a wide variety of vegetation types common to the coastal environment. Vegetation in the upland areas commonly consists of 
dense forests with a very heavy understory. Sitka spruce (Picea sitchensis), Western hemlock (Tsuga heterophylla), Western red cedar (Thuja plicata), and Red alder (Alnus $\underline{\text { rubra) }}$ are the dominant trees; and they are in association with understory plants such as: Swordfern (Polystichum munitum), Oregon oxalis (Oxalis oregana), Rusty leaf (Menziesia ferruginea), and Western spring beauty (Monita sibirica). Lodgepole pine (Pinus contorta) and Sitka spruce (Picea sitchensis) are common on dunes and terraces, as are understory forms such as: European beachgrass (Ammophila arenaria), Pacific rhododendron (Rhododendron macrophylum), Evergreen huckleberry (Vaccinium ovatum), and Salal (Gaultheria shallon).

The marsh lands and tidal flats support yet another group of vegetation types. Plants most commonly found in these areas include: Seaside arrowgrass (Triglochin maritima), Seashore saltgrass (Distichlis spicata), Western Lilaeopsis (Lilaeopsis occidentalis), Slough sedge (Carex obnupta), and Silverweed (Pottentilla anserina). A more detailed description of Oregon's coastal vegetation is contained in Vegetation of Oregon and Washington (Franklin and Dyrness, 1969).

The role of vegetation will be discussed in relation to specific landforms in a later section.

\section{PREVIOUS WORK}

Regional geologic studies and mapping, covering a11 or part of the study area, have been conducted by Snavely and Vokes (1949); Vokes, Norbisrath, Hans, and Snave1y (1949); Snavely and Wagner (1963); Snavely, Rau and Wagner (1964); Snavely, Macleod and Rau (1969); and 
Snavely, MacLeod and Wagner (1972).

Descriptions of various landforms in the study area, or of similar landforms elsewhere on the Oregon coast have been presented by Diller (1902), Smith (1933), Allen and Baldwin (1944), Baldwin (1945, 1959), Griggs (1945), Cooper (1958), Palmer (1967), and Lund (1972).

Investigation results and discussions of various geologic hazards similar to those present in the study area are contained in Dole (1954); Schlicker, Corcoran, and Bowen (1961); North and Byrne (1965); and Sheppard and Wanless (1971).

The report by Schlicker, Deacon, Beaulieu, and O1cott (1972) covers the environmental geology of the northern portion of Oregon's coast, but contains information that was quite useful to this report.

\section{ACKNOWLEDGEMENTS}

The development of my interest in the application of geology to man's environmental problems should be credited to the entire faculty and staff of the Portland State University Earth Science Department. This group's awareness and knowledge of the relationship of geologic conditions and processes to man's natural environment was passed on to me through classroom instruction, field projects, and personal communication.

The opportunity to further develop this interest was provided by the Oregon State Department of Geology and Mineral Industries. In the summer of 1972 that organization provided financial assistance which allowed me to begin the field studies for this project. Since that time I have received academic and financial assistance, as well as moral support from numerous individuals and organizations. 
Assistance in formulating and carrying out the field work for the project was provided by Dr. Leonard Palmer, my graduate advisor at Portland State University, and by members of the State Department of Geology staff that were working concurrent1y on an environmental geology study of Lincoln County, Oregon. Those members of the staff that were of considerable assistance include Mr. Raymond Corcoran, state geologist, Mr. Herb Schlicker, engineering geologist, and $\mathrm{Mr}$. John Beaulieu, stratigrapher. Mr. Mel Rigdon and his associates at the Lincoln County Soil Conservation Service office in Newport provided soils information and aerial photographs that were very helpful during the early stages of the project, and the ideas provided by Mr. Joe Meyers, soil scientist and environmental geologist, had a strong influence on the development of the study's format.

During the period following the field work and preceding the drafting of the report, assistance, in a variety of forms, was provided by friends, student associates, and the Portland State University Earth Science staff. Those whose help was most valuable include Arden Callender, Dave Lofgren, Jim Cassidy, Greg Paul, Andy and Connie Ewing, Chris Lewis, Virginia Leihy, Gene Pierson, Hal Scofield, and the Vaughn Taunton Family.

Despite a very busy schedule, Dr. Len Palmer was able to devote a good deal of time to the editing of the rough and final drafts of the report. His help during this stage was invaluable. Further editing by Dr. Richard Thoms and Dr. John Allen added considerably to the quality of this report.

I am most grateful for the assistance which I have received from 
all of those mentioned above, but my most sincere thanks go to the members of my immediate family and to Bev Siers without whose financial assistance and moral support this study could not have been completed. 


\section{CHAPTER II}

MAJOR LANDFORMS

The critical limitations to land use development and preservation can be grouped according to major subdivisions of landforms. Each landform has peculiar characteristics of origin, materials, active processes, soils, vegetation, ground water, stability, and engineering properties.

In this section the landforms will be defined according to (a) their physical characteristics and variations of those characteristics, (b) their distribution and relation to other landforms (shown in Fig. 28), (c) their function within the coastal environment, and (d) how they can be used by man without destroying that function. Other landform characteristics such as engineering properties, and hazards will be discussed in later sections.

Seven distinct geomorphic landforms can be differentiated within the study area. These include: the beaches, active dunes, stabilized dunes, marsh lands and tidal flats, marine terraces, basaltic headlands, and upland areas. Examples of each type are shown in Figs. 4 through 11 . 


\section{BEACHES}

The beaches are herein defined as the deposits of sediment laid down by ocean wave action including seasonal extremes of wave action produced by tides and storms. A beach is formed by wind and wave abrasion and erosion of the coast and deposition by active longshore sediment transport. The beach extends from the base of wave action on the sea floor to the sea-cliff, or to the extreme landward extent of storm wave action. Beach forms include the gently sloping foreshore, berms, bars and spits.

Varieties of beaches in the study area include those backed by sea-cliffs and those with dunes, spits, or other landward margins. There are also long continuous beaches, and short "pocket" beaches. Beach materials consist primarily of unconsolidated sand and grave1size sediment usually, with the exception of pocket beaches, in the process of active longshore transport. Because the beach materials are subject to frequent erosion and transport, they do not commonly support vegetation (some hearty sea grasses such as European beachgrass do establish themselves on prograding beaches).

Broad continuous expanses of sand beach are distributed along approximately 75 percent of the ocean shoreline in the study area. These are interrupted only by occasional headlands, or by stream and bay mouths. The major stretches of beach are those from the Siletz Bay mouth to Fishing Rock, Otter Rock to the north side of Yaquina Head, the south side of Yaquina Head to Seal Rocks, and from the south side of Seal Rocks to the southern border of the study area (see Fig. 28). The remainder of the ocean shoreline is made up of the headlands 
of the Cape Foulweather volcanic complex, Otter Rock, Yaquina Head, and Sea1 Rocks. Numerous picturesque pocket beaches occur along these portions of the shoreline. The beaches at Whale Cove and Seal Rocks are excellent examples of this type of feature.

The natural processes in the beach area are extremely active. Seasonal variations in wave action operate to balance erosion, transportation, and distribution of all unconsolidated beach sediment. To sustain a natural beach environment all three of these processes must be maintained. The beach is a self-cleaning, self-renewing environment that is aesthetically pleasing and that supports a variety of recreational activities. In addition, the ability of the beach to absorb wave energy aids in the protection of inland areas from wave destruction. Any interference with beach processes may result in the destruction of the beach as a natural system and even lead to erosional or depositional conditions hazardous to man.

\section{ACTIVE DUNES}

Active dunes are wind blown deposits of sand size material with very little or no vegetative cover. They are unconsolidated and subject to shifting and relocation. They may vary greatly in size, slope, and shape with their long dimension ranging from a few tens of feet to tens of miles (a few meters to tens of kilometers), (Cooper, 1958). The size, shape, and slope of active dunes are directly related to the amount of available sand, wind direction, wind velocity, and wind duration. For planning purposes, dunes of two varieties are important: those which are active, described here; and those which have developed 
vegetative cover, soils, and are stabilized, described in the next section.

Small active dunes are found in a variety of backshore areas, stream mouths, or in depressions in marine or stream terrace surfaces. Extensive dune complexes, [greater than $300 \mathrm{ft}(91.4 \mathrm{~m})$ in length], are found only on Siletz spit, the south side of Yaquina Bay, north of Beaver Creek, and on the north side of the mouth of Siletz Bay.

Although dune processes are less active than beach processes, the shifting of sand by wind is a nearly constant motion system in which subtle changes in the controlling mechanisms (wind, vegetation, and sediment supply) can cause major changes in the stability, rate, and direction of movement.

Active dunes have positive benefits for man which are quite similar to those of beaches. They are self-renewing, aesthetically pleasing, support recreational activities, and protect inland areas. However, shifting dunes may conflict with man's attempt to establish fixed facilities such as homes, industrial sites, or transportation facilities.

\section{STABILIZED DUNES}

A stabilized dune is like an active dune in every respect except that it has acquired surficial stability through growth of ground covering vegetation, and has developed a soil horizon. Maximum slopes (5 to 15 percent) are generally less than that of the active dune slip face. Stabilized dune sands are frequently quite similar in appearance to the older marine terrace sands (to be described later). This is because the dune sands have undergone weathering and/or depo- 
sition of organic and ground water originated deposits which discolor the sands to a rusty-reddish-brown color, and provides a weak cementation.

Active dunes become stabilized when they develop a vegetative cover adequate to protect them from wind erosion, when they shift away from the exposed beach area, or when they are isolated from the beach by tectonic uplift or a lowering of sea level. Most stabilized dunes are found at a distance from the beach on the landward margin of the dune complex, or commonly, on the marine terraces. In the study area stabilized dune complexes are found on the southern portion of Siletz Spit, north and southeast of the mouth of Yaquina Bay, north of Beaver Creek, and just west of Highway 101 approximately one and one-half miles north of Waldport. These stabilized dune areas are shown on the landforms map (Fig. 28).

The continued stability of these dunes is dependent upon the protective cover of vegetation. Without the cover, a stabilized dune may again become active. As long as they remain stable, they are suitable for ground water storage, forest growth, and certain residential or commercial development. Considerable care must be exercised to maintain the stability of these landforms through attention to proper ground cover maintenance.

\section{MARSH LANDS AND TIDAL FLATS}

Marsh lands and tidal flats have been grouped under one category because of their similarities. They are flat or gently sloping, lowlying areas which are subject to frequent flooding during a major portion of the year. Tidal flats are formed by drowning of ancient 
river and stream mouths due to a rise in sea leve1, or subsidence of the coastal 1and. Marsh lands in the study area are low-lying areas on the land surface formed by wind or water erosion and deposition. Tidal flats are inundated by salt water during periods of high tide; whereas marsh lands are subject to fresh water flooding from high stream flow or a rising ground water table.

Highly organic unconsolidated sands, silts, and clays underlie these wetlands, and pockets of peat commonly occur in areas where plant growth is concentrated. No information on the depth of these finegrained deposits in the study area was available; but sediment depths of well over $100 \mathrm{ft}(30.5 \mathrm{~m})$ have been recorded on similar features to the north of the study area (Schlicker and others, 1972).

Major tidal flats occur on the edges of the three main estuaries, and marsh lands occur in the interdune areas north of Alsea Bay, and in numerous stream mouths along the entire section of coast line (see Fig. 28). On the soil series map (Fig. 27), tidal flats are shown as Tf, and marsh lands as Wa (W stands for Warrenton soils - the soil type common to marsh 1 and regions).

Marsh lands and tidal flats, with their shallow warm waters, are natural centers of nutrient production, and are breeding grounds for organisms in the first link of the complex food chain upon which aquatic life forms depend. Active natural processes such as stream sedimentation and vegetation growth tend to fill in and slowly destroy these vital environments.

Man benefits directly from these wetlands by their sustenance of the sea food and fishing industries, and of a wide variety of bird life. Both the aesthetic value of the fish and bird life and the 
economic benefits of the fishing industry are vital to the coastal welfare.

\section{MARINE TERRACES}

A marine terrace is an elevated wave-cut bench. It is formed by a change of sea level, or uplift of the coastal 1 and area. Either of these two have the effect of elevating the beach to a higher position where it is no longer subject to beach processes. The ancient beach form is then modified by wave erosion at the toe, by surficial erosion, and by deposition of colluvial debris. If dunes were present on the old beach, they may be preserved on the terrace as stabilized dunes. The terrace form (Fig. 3) consists of an abrasion platform, often overlaid by marine, eolian, and colluvial unconsolidated deposits. In the study area this terrace cover material ranges from 0 to more than $50 \mathrm{ft}(15.2 \mathrm{~m})$ in thickness, and has in places been severely dissected by wind and stream erosion.

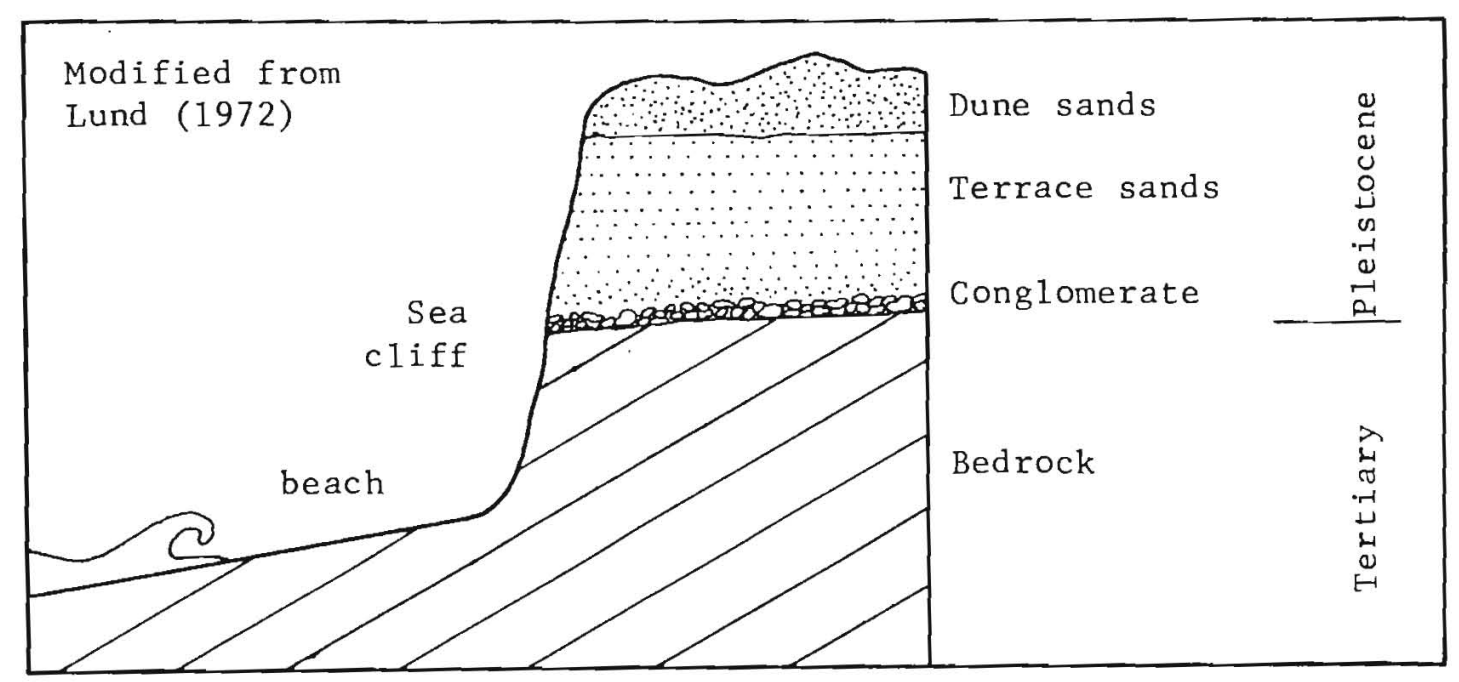

Figure 3. Generalized marine terrace features. 
Marine terraces are the dominant landform covering approximately 35 percent of the study area. They occur commonly between sea leve1 and $250 \mathrm{ft}(76.2 \mathrm{~m})$ elevation. Other, less important terrace features have been reported as occurring at $400 \mathrm{ft}(122 \mathrm{~m}), 800 \mathrm{ft}(244 \mathrm{~m})$, and as high as 1,000 ft (305 m) elevation (Palmer, 1967; Snavely, 1963). Terrace features extend nearly continuously along the study area shoreline (Fig. 28). Widths of these features range from a few tens of feet (several meters) to over $3,000 \mathrm{ft}(914 \mathrm{~m})$.

No constructive processes are presently known to be forming new marine terrace landforms. Existing terraces, however, are being modified by wave, wind, and stream erosion and deposition.

These relict beach platforms now provide a naturally excavated shelf for occupation by man. They provide excellent locations for transportation facilities, agricultural or industrial development, beach access, and a variety of other uses. If proper planning, based on an evaluation of natural characteristics, is used, the development of terrace areas has very little detrimental effect on the coastal environment.

VI. BASALTIC HEADLANDS

A headland is a projection of land into the sea. In the study area, headlands are dominantly formed of resistant basaltic rock, the remnants of Miocene volcanic activity (more than 10 million years ago). They range in length from a few tens of feet (several meters) to over a mile $(1.6 \mathrm{~km})$, and have heights to over $1,000 \mathrm{ft}(305 \mathrm{~m})$. Extremely steep slopes are common on volcanic headlands with sea-cliffs dropping precipitously into the sea. Wave action undercuts the headland sea- 
cliffs, and may also isolate a headland from the shore, forming a sea stack. Joints and fractures are common in the basaltic rock, and cause severe problems of rock fall and other forms of mass wasting on the headlands. Vegetation is limited by the steep slopes and shallow soils. Headlands in the study area are nearly continuous for about nine miles (14.5 km) from Devils Punch Bowl to Fishing Rock. One prominent headland extends one mile $(1.6 \mathrm{~km})$ into the sea at Yaquina Head, and numerous small headlands and sea stacks are formed at Seal Rocks (Fig. 28).

Wave action at headlands is focused by wave refraction to extreme violence. The headland sea-cliffs are undercut and sustained by these forces, and there is little that man can do to mitigate such processes. The spectacle of rugged headlands under storm wave action is a favorite scenic asset of the Oregon coast. It is a favorite subject of paintings and photographs, and a tourist attraction of considerable value. Dangers from the steep cliffs, wave action, and rock falls are severe; and it is difficult to justify any intrusion into the headland areas by man-made structures.

VII. UPLANDS

The uplands of the study area are the western flank of a portion of the Oregon Coast Range. They consist primarily of marine sedimentary materials that have been uplifted and tilted to the west by tectonic processes, severely dissected by numerous streams and rivers, and further modified by extensive mass wasting. Deep soils have developed on the soft bedrock material and now support dense evergreen forests with extremely thick understories. Within the study area the uplands 
rise to elevations of $650 \mathrm{ft}(198 \mathrm{~m})$ and make up approximately $30 \mathrm{per}-$ cent of the land area.

Variations of upland areas in relation to planning, depend on the type of bedrock material, bedrock structural characteristics, thickness of soil, and degree of erosion. Those areas with conditions such as weak sedimentary or volcaniclastic bedrock, steep slopes, deep soils, or steeply dipping bedding planes present the greatest problem. This combination of detrimental characteristics is common in the study area upland regions. On the other hand, upland areas with massive sandstone or volcanic bedrock, gentle slopes, shallow soils, and gently dipping bedding planes or flow contacts are more suitable for development. Upland areas occur along the eastern margins of the three main estuaries within the study area (Fig. 28), but these represent only a very small portion of similar landforms which extend along nearly the entire length of the Oregon and Washington coasts.

Active processes in the upland areas include soil formation, various forms of mass wasting, and stream erosion. In addition, the uplands are the collection areas for the tremendous amount of rainfal1 [ 50 to 120 inches per year ( 1.3 to 3 meters per year)] that supplies the coastal streams and rivers. The streams and rivers are vital to water supply, beach sediment supply, aesthetic beauty, and recreation. The deep soils of the uplands support the great forests that have been the mainstay of coastal industries.

A great majority of the coastal uplands are under control and ownership of timber interest or government. However, upland regions within and adjacent to the study area are becoming more and more 
desirable as residential and commercial properties. Land use and ownership changes in these areas seems imminent. Land use planning and development control are definitely needed in these areas. 


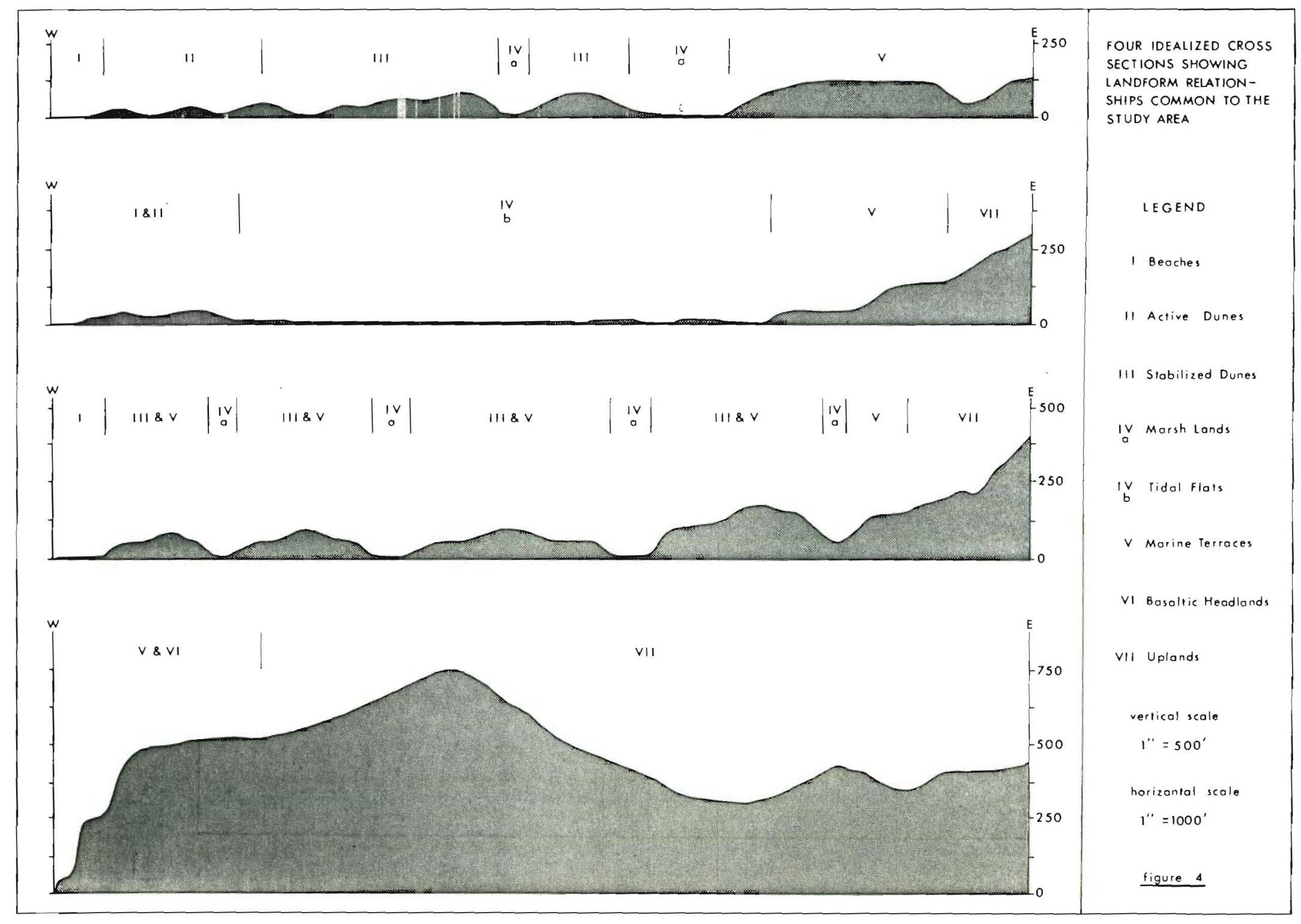




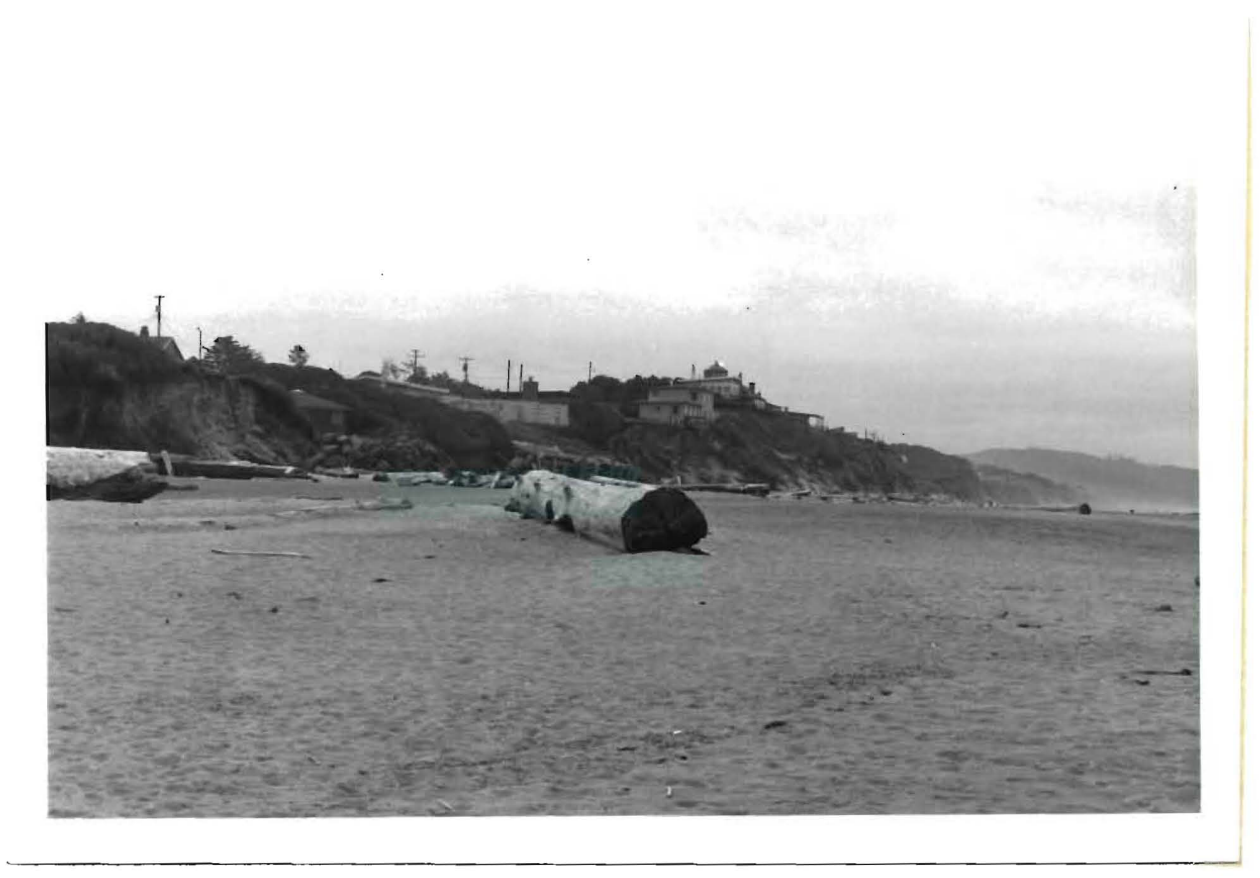

Figure 5. Broad sand beach - 2 miles north of Fishing Rock.

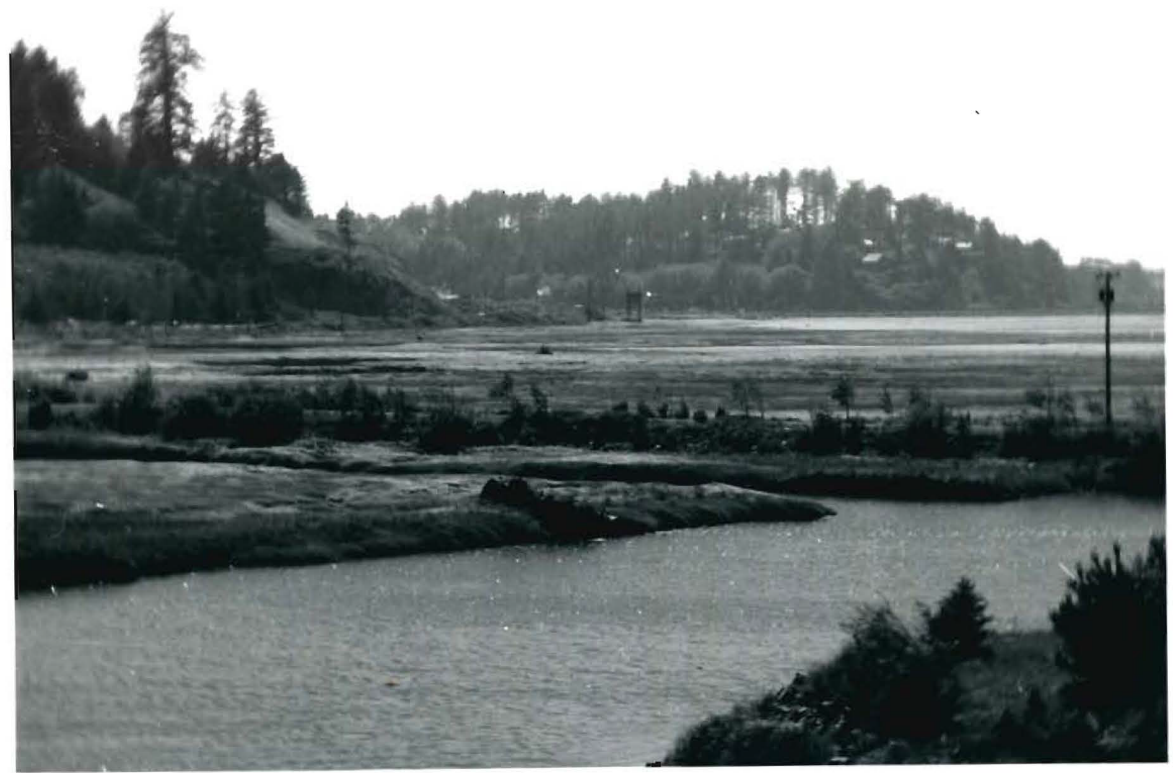

Figure 6. Marsh lands and tidal flats on the southeast side of Siletz Bay. 


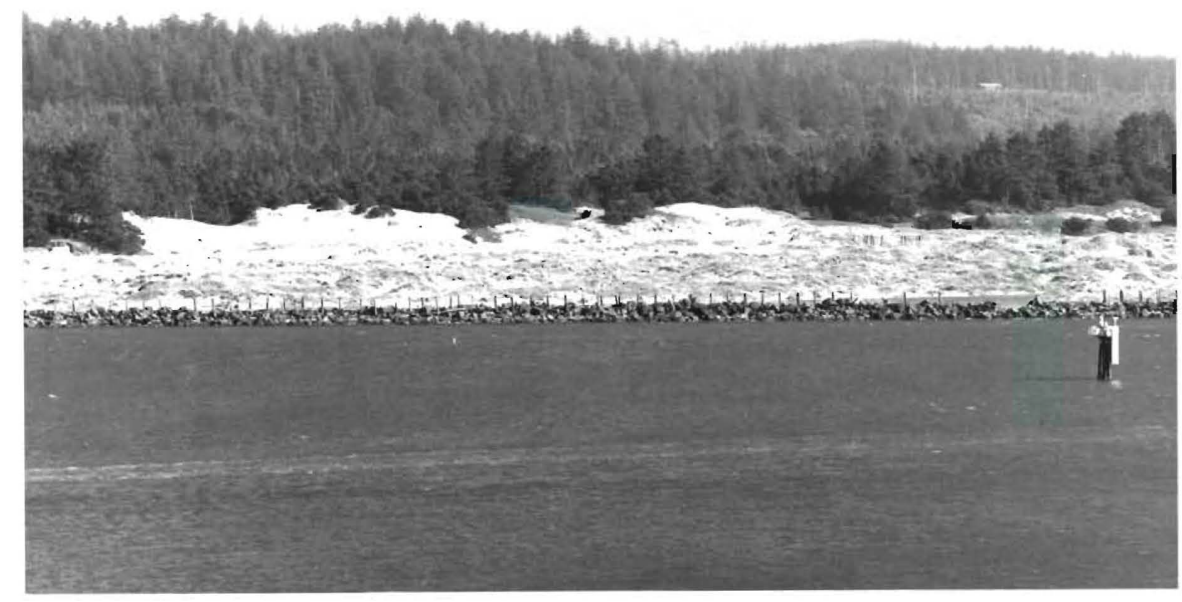

Figure 7. Active dunes - view is southward across the mouth of Yaquina Bay.

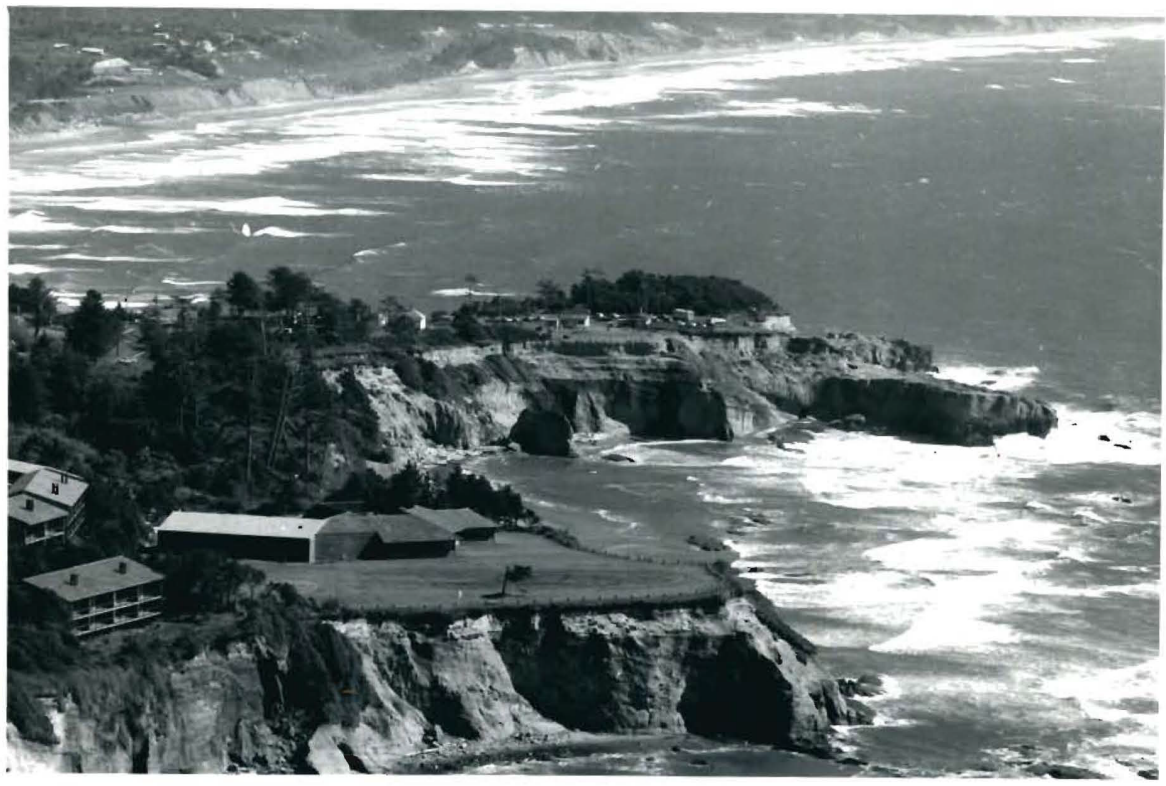

Figure 8. Marine terraces near Otter Rock - view is southward from Otter Crest State Park. 


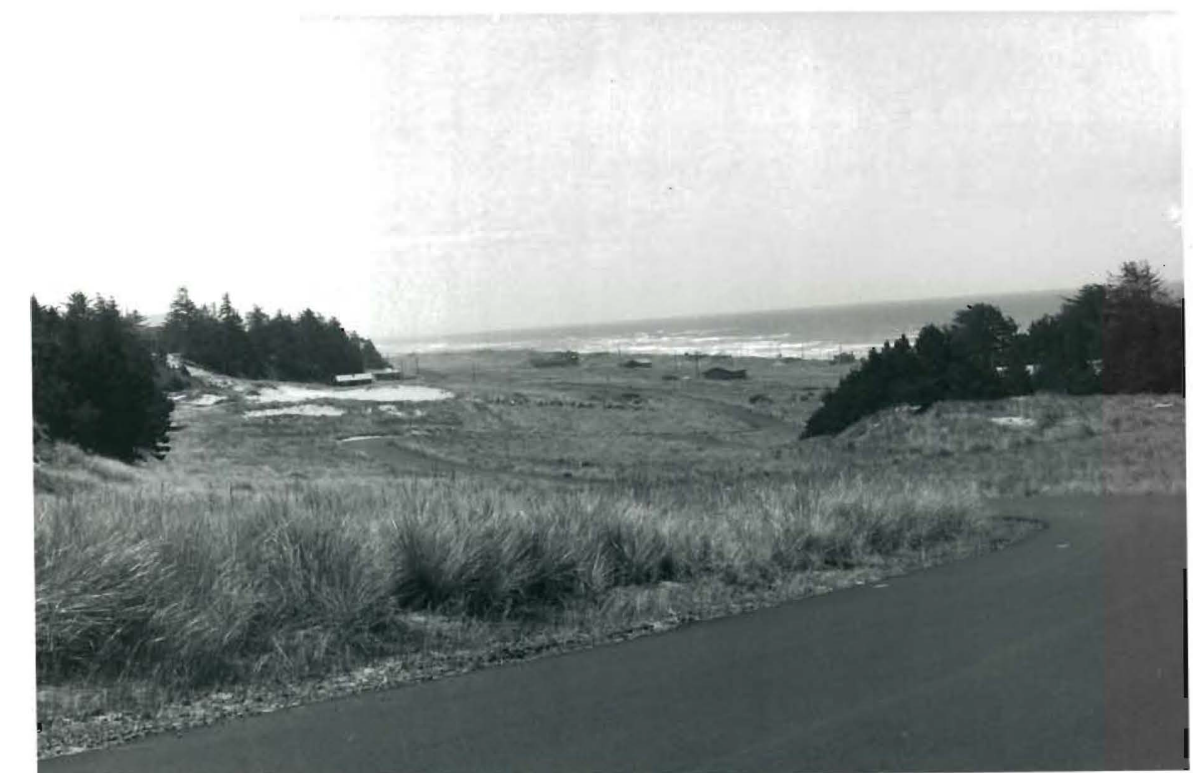

Figure 9. Stabilized dunes with sea-grass and localized forest cover - view is southward along the spit at Alsea Bay.

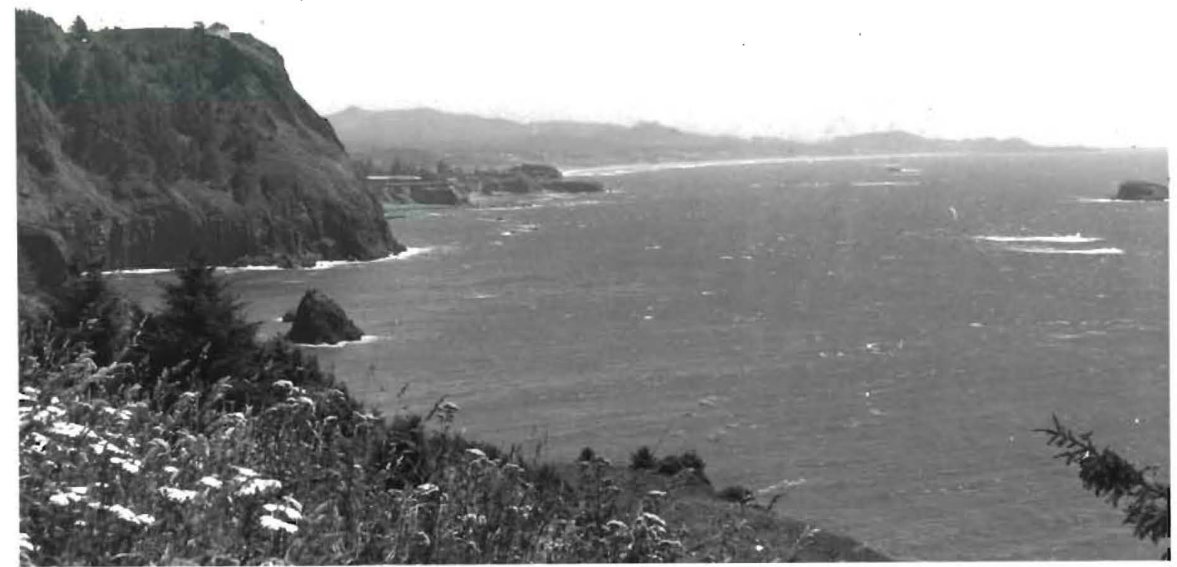

Figure 10. Basaltic headland of Otter Crest - view is southward from Cape Foulweather. 


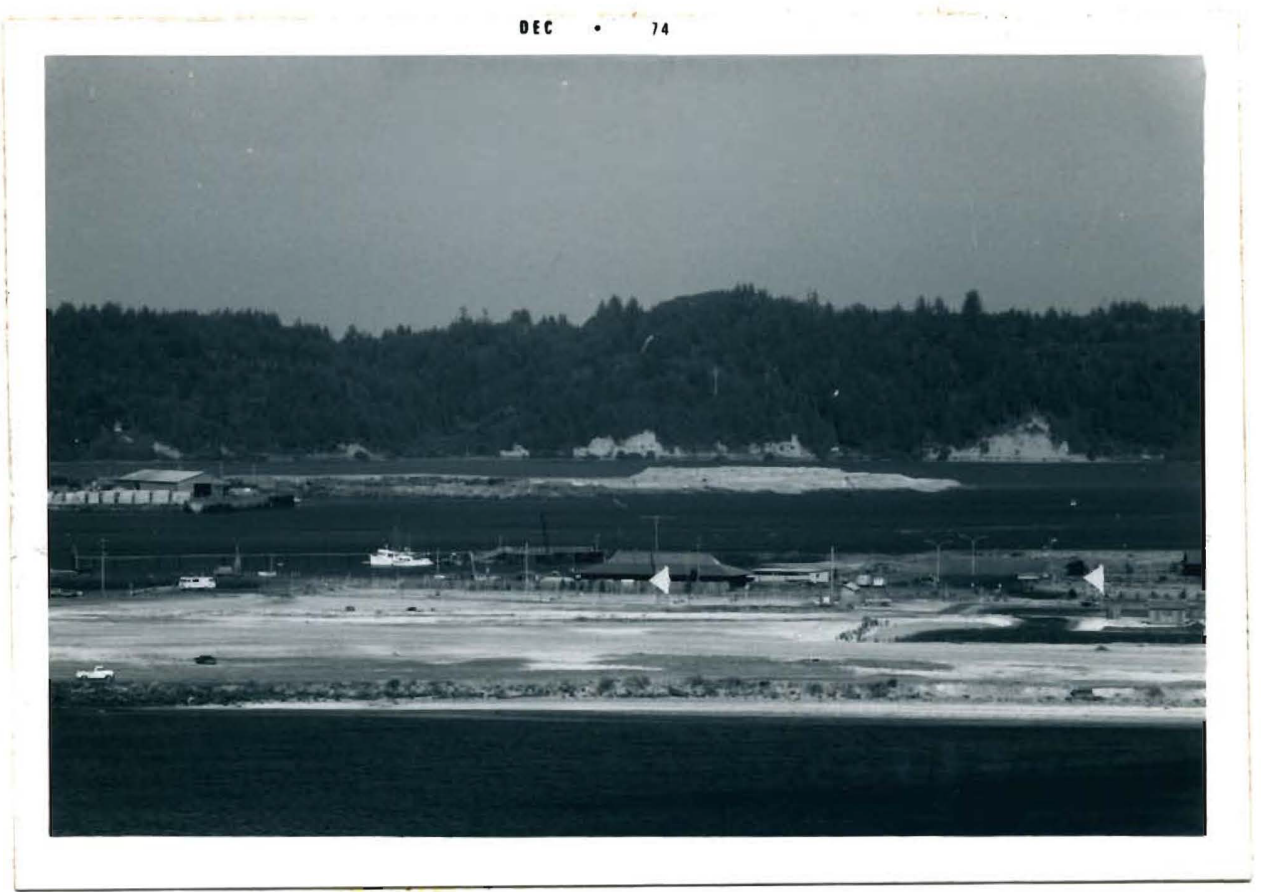

Figure 11. Uplands on the eastern edge of Yaquina Bay. 


\section{CHAPTER III}

\section{GEOLOG IC HISTORY}

Present geologic conditions on the Oregon coast represent the current stage of processes which have been active for millions of years, and that will continue to be active for millions more. In order to deal with the current geological conditions of the Oregon coastal environment, it is necessary to observe the evidence of all stages of past geologic activity in the area, and use the knowledge gained from these observations to explain and deal with current or future conditions. Detailed descriptions of the geologic history of the coastal areas of Oregon and Washington by Snavely and Wagner (1963), and Snavely, Macleod, and Rau (1969), indicate that rocks of Early Eocene to Pliocene age were being deposited in a deep marine trough environment of continually lessening dimensions. The situation of the trough axis along the boundary between the active North American and Pacific plates (according to present global tectonic theory) resulted in a complex history of mountain-making activity, extrusive and intrusive igneous activity, and continual deposition of sediments derived from within the trough as well as from upland areas south and west of the trough. The processes active at this plate boundary in the past and at present are not completely understood. Continuing research is necessary to determine the present and future effect of these processes on the coasta1 environment.

The following paragraphs contain an abbreviated geologic history 


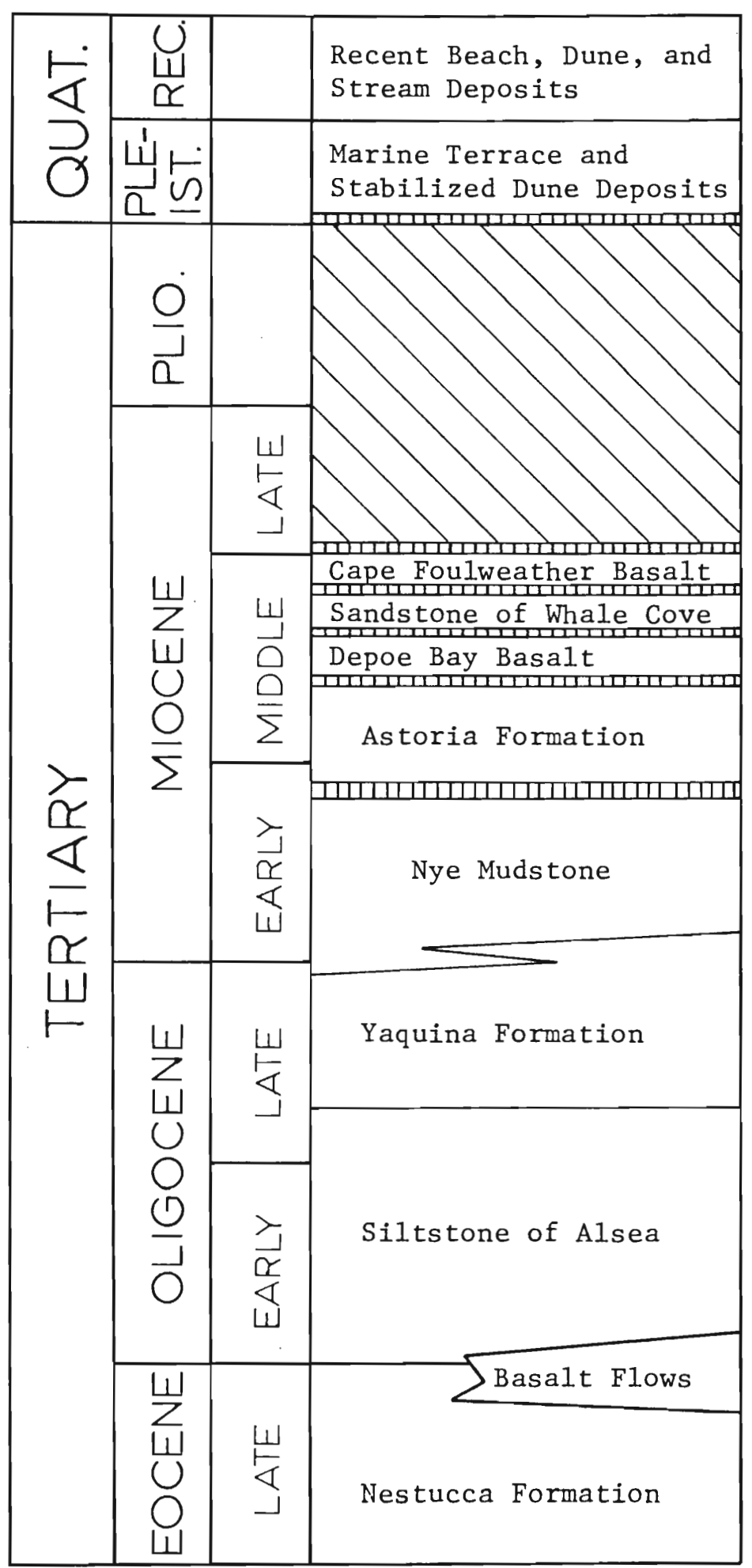

Derived from Baldwin (1964), and Snavely and others (1969).

Figure 12. Stratigraphic column. 
of the study area derived primarily from three, more detailed reports: Snavely and Wagner (1963); Snavely, MacLeod, and Rau (1969); and MacLeod and Snave1y (1973).

I. EOCENE

(Approximately $40-60$ million years ago)

The oldest rocks exposed within the boundaries of the study area are part of the Upper Eocene Nestucca Formation. The Nestucca Formation represents the first stages of renewed deposition following a middle Eocene period of deformation and erosion. The result of this period of deformation had been the division of the original, continuous, depositional trough into several smaller, interconnected basins.

The Nestucca Formation is exposed only in the south east portion of the study area, where it consists of thin-bedded tuffaceous siltstone. Fossil assemblages from within the Nestucca are indicative of a 600 to $1,000 \mathrm{ft}$ (183 to 305 meter) deep marine environment. Terrains underlaid by this unit are subject to massive 1 andslides (Schlicker and others, 1972).

\section{OLIGOCENE}

(Approximately $30-40$ million years ago)

Deposition continued uninterrupted into the Oligocene Epoch. The first stage of this deposition consisted of some $1500 \mathrm{ft}(457 \mathrm{~m})$ of massive to thick-bedded tuffaceous silt-stone to very fine-grained sandstone. This unit has been informally referred to as the "Siltstone of Alsea;" and, within the study area, is exposed north and 
south of Alsea Bay, on the eastern edge of Siletz Bay, and along the coast line from Seal Rocks to the southern boundary. Considerable amounts of ash, thought to be from Cascade volcanism, is included in the "Alsea" as are interbeds of glauconitic sandstone and pumiceous mudflow breccia. Fossil evidence indicates depths in the marine environment ranging from $300 \mathrm{ft}$ to $2,000 \mathrm{ft}$ ( 91.4 meters to 610 meters) during deposition of the Alsea siltstone.

The Alsea siltstone is easily weathered, and, as a result, forms deep soils and is subject to soil creep and landslide activity (Sch1icker and others, 1972).

The Yaquina Formation of Upper Oligocene age consists of massive to we11-bedded and cross-bedded sandstone, siltstone, and conglomerate ranging in thickness from $1,000 \mathrm{ft}(305 \mathrm{~m})$ to $2,000 \mathrm{ft}(610 \mathrm{~m})$. It is exposed along the eastern edge of Yaquina Bay, and along a short stretch of coast line from Beaver Creek to Seal Rocks. Sedimentary structures, such as large scale cross-bedding, foreset bedding, and cut and fill structures, along with the distribution of the Formation and variety of materials included suggests that it represents a deltaic deposit. Abundant andesitic pumice clasts in the Yaquina Formation indicate continuing volcanic activity in the Cascades.

In the study area, landsliding is quite common on terrain underlaid by the Yaquina Formation.

\section{MIOCENE}

$$
\text { (Approximately } 10-30 \text { million years ago) }
$$

Intertonguing occurs between the upper portions of the Yaquina Formation and the basal portion of the overlying Nye Mudstone of 
Miocene age. Lower portions of the Nye may be late Oligocene, but the major portion of the formation is of early Miocene age, and consists predominantly of medium to dark gray massive organic rich mudstone and siltstone, with calcareous and dolomitic concretions - up to four feet $(1.2 \mathrm{~m})$ across - and lenticular beds - up to one foot $(0.3 \mathrm{~m})$ thick occurring locally. The Nye outcrops on the north and south side of Yaquina Bay, and in the sea-cliffs from Yaquina Head south to Beaver Creek. The Nye sediments were deposited in an upper bathyal marine environment, $1,000 \mathrm{ft}$ to $2,000 \mathrm{ft}(305 \mathrm{~m}$ to $610 \mathrm{~m})$.

Areas underlaid by the fine-grained, organic-rich sediments of the Nye Formation are subject to massive landsliding activity.

Tectonic activity to this point had been limited to broad regional uplift or subsidence of portions of the depositional trough with very little resultant deformation of the sedimentary fill. During early middle Miocene time the depositional sequence was temporarily interrupted by gentle folding and faulting of the older Tertiary strata. In the study area this activity is evidenced by a slight angular unconformity between the Nye Mudstone and the overlying sandstones of the Astoria Formation (also Miocene).

The Astoria Formation in the study area consists of olive gray to light brown medium-grained, massive to thin-bedded micaceous, arkosic sandstone, and dark gray carbonaceous siltstone. Occasional yellow-gray siliceous tuff beds of varying thickness and dacitic to andesitic composition are evidence for continuing volcanic activity. Variable thicknesses have been reported for the Astoria Formation, but the maximum onshore thickness is some $2,000 \mathrm{ft}(610 \mathrm{~m})$ in the Newport Area. The Astoria Formation is exposed in the sea-cliffs from 
Siletz Bay to Yaquina Bay. The most continuous exposed section is Otter Rock south to Yaquina Head. Fossil assemblages indicate deposition in a shallow marine environment of possibly not more than $500 \mathrm{ft}$ (152 m) .

The Astoria Formation is somewhat more resistant than other Tertiary sedimentary material in the study area, but massive landslide topography is typical of terrain underlaid by this Formation.

Volcanism was the dominant process during late middle Miocene time. Two basaltic units, the Depoe Bay Basalt and the Basalt of Cape Foulweather, were erupted from volcanic centers located near the MidMiocene strand line. In certain areas the two units are separated by some $300 \mathrm{ft}(91 \mathrm{~m})$ of clastic sedimentary rocks referred to as the "Sandstone of Whale Cove."

The Depoe Bay Basalt, the older basalt unit, unconformably overlies the Astoria Formation, and consists of sub-aerial columnar basalt flows that grade into breccia with isolated pillows. The isolated pillow structures, which indicate submarine origin, are commonly two to four feet $(0.6$ to $1.2 \mathrm{~m})$ across. Excellent exposures of this unit can be seen at the type locality, Depoe Bay. Intrusive equivalents of this unit outcrop in the hills east of Depoe Bay, and along the east edge of Siletz Bay.

The Depoe Bay Basalt has a fairly high resistance to erosion, and is quite stable, with the exception of rock falls which are common on steep slopes.

The Sandstone of Whale Cove overlies the Depoe Bay Basalt, and is composed of massive to thick-bedded, medium to fine-grained sandstone derived primarily from re-working of older Tertiary sediments. Cross- 
bedding, cut and fill, and other sedimentary structures are quite common in the Whale Cove Sandstone. Excellent exposures of these sandstones occur on the sea-cliffs at outer Depoe Bay and at Whale Cove approximately one mile $(1.6 \mathrm{~km})$ south of Depoe Bay.

In the study area the Sandstone of Whale Cove occurs on $1 y$ on leve1 or gent1y sloping terrain, and as a result, is not subject to hillside erosion or mass wasting. Sea-cliffs of this material, however, are subject to fairly rapid erosion.

The youngest of the three late middle Miocene units, the Basalt of Cape Foulweather, unconformably overlies the Sandstone of Whale Cove (when that unit is present), the Depoe Bay Basalts, or the Astoria Formation. It is composed of basaltic breccia, waterlaid fragmental debris, flows, and pillow lavas; and intrusive features, such as volcanic necks and feeder dikes are exposed at the type locality Cape Foulweather. Volcanic material associated with this unit dominates the coast line for a six mile $(9.6 \mathrm{~km})$ stretch extending from Government Point south to Otter Rock, and makes up the headland of Yaquina Head some four miles $(6.4 \mathrm{~km})$ north of Newport. Intrusive material of the Cape Foulweather type makes up the sea stacks and sma11 headlands of Seal Rocks eight miles $(12.8 \mathrm{~km})$ south of Newport.

Like the Depoe Bay Basalt, the Basalt of Cape Foulweather is quite resistant to erosion but subject to rock fall or rock slides when exposed on steep slopes.

Considerable uplift of the Coast Range occurred during late Miocene time. This tectonic activity moved the depositional trough westward beyond the present shoreline, and imparted westerly dips of from 10 to 20 degrees to those older Tertiary rocks on the west flank of 
the coast range.

$$
\begin{gathered}
\text { IV. PLIOCENE } \\
\text { (Approximately } 1-10 \text { million years ago) }
\end{gathered}
$$

No late Miocene or Pliocene rocks are exposed in the study area, but geophysical exploration and drilling projects have shown that several thousand feet of Pliocene sediments do occur directly offshore from the study area.

V. QUATERNARY

(Present to 1 million years ago)

Quaternary deposits cover approximately 70 percent of the surface within the study area, but they have not been extensively studied to date. For the most part, the Quaternary record consists of semi-consolidated to unconsolidated mud, sand, silt, and gravel that cap the elevated marine terraces that are quite common between sea level and $250 \mathrm{ft}(76.2 \mathrm{~m})$ elevation. There is not yet a complete understanding of the processes or time involved in the formation of the terrace features. They are most likely the result of continual uplift of the coastal area combined with glacial related fluctuations of mean sea level.

In addition to the terrace deposits, estuary fill material, stream deposits and dune features represent other forms of Quaternary activity. Most recent geologic activity in the study area has included: (a) post-Pleistocene eustatic rise of sea level and resulting drowning of coastal stream and river mouths to form estuaries, (b) partial filling of these estuaries, (c) stream and shoreline processes, (d) dune form- 
ation, (e) extensive large scale sliding and slumping, and ( $f$ ) periodic minor earthquake activity.

Nearly all of the Quaternary deposits are highly unstable or subject to rapid erosion by ocean waves, wind, or surface water.

Certain aspects of the geologic history of the study area, such as the inclusion of volcanic ash and organic material in nearly all bedrock formations, strand line volcanic activity, development of regional westerly dips, and elevation of several marine terraces, have played a critical role in the formation of current environmental conditions. An understanding of the historical development of these conditions is a valuable tool when attempting to deal with current or future problems resulting from them. 
CHAPTER IV

\section{GEOLOGIC AND ENGINEERING CHARACTERISTICS \\ OF THE MAJOR LANDFORM TYPES}

This section describes the geologic and engineering characteristics of those landforms defined in the section on major landforms. Each of the major landforms has characteristic rock type, soils, hydrologic properties, and engineering qualities that help to define its land use limitations. Most of the information in this section of text is summarized in chart form in Table $I$. Information on the engineering qualities and soils was taken from Schlicker and others (1972), Portland Cement Association (1962), and Oregon State Water Resources Board (1969).

Certain relative terms used in this section, such as moderate, poor, good, etc., are defined in Appendix A. For specific projects the geologic and engineering characteristics must be individually determined on a site-evaluation basis. Values indicated here are for broad planning and preliminary use only.

\section{BEACH AND ACTIVE DUNES}

These two landforms have been grouped together because they have very similar geologic and engineering characteristics. 
Rock Type

The beach and active dune landforms are made up primarily of sub-angular to rounded, medium to fine-grained quartzofeldspathic sand (Cooper, 1958).

$\underline{\text { Soil }}$

These landforms have no developed soil horizon.

Hydrologic Properties

These sands have good drainage with very high permeability and high porosity. Beach materials are subject to tidal and/or wave inundation, but extensive dune areas (collect significant amounts of rainwater and) are potentially good aquifers. Schlicker and others (1972) indicate that dunes may provide adequate water supply for local domestic use in coastal regions.

\section{Engineering Qualities}

Beach and dune sands are easily excavated with a bulldozer blade, but even gentle ( 0 to 12 percent) slopes - natural, fill, or cut - are prone to failure if not supported or protected by cover. The unconsolidated sands have an approximate California Bearing Ratio (CBR) of 30 and will support light buildings with spread footings of adequate dimension.

\section{STABILIZED DUNES}

\section{Rock Type}

Stabilized dunes are made up of relatively unconsolidated subangular to rounded quartzofeldspathic sand. 
Soil

Soils on these stabilized dune features are commonly 30 inches to 60 inches $(76 \mathrm{~cm}$ to $152 \mathrm{~cm}$ ) deep, and are classified as fine-sand or loamy fine-sand.

\section{Hydrologic Properties}

Stabilized dunes have good drainage with high permeability, fair1y high porosity, and low runoff. Interdune areas are an exception in that they often have a high ground water table. Large areas of stabilized dunes may have potential for future water supply. The one well record available for such an area (dune complex south of Yaquina Bay mouth) indicated a capacity of 25 gpm with very little draw down.

\section{Engineering Qualities}

Stabilized dunes have engineering characteristics similar to those of active dunes. They are easily excavated by a bulldozer blade, but exposed slopes are subject to rapid erosion, as evidenced in many road cuts in the study area. The dune soils have an approximate CBR of 17 , and will support low load structures if the slopes of the dune are not too steep, and if the foundations are not subject to undercutting by erosion.

\section{MARSH LANDS AND TIDAL FLATS}

\section{Rock Type}

Rock types associated with these landforms are fine sands, silt, and clay derived from erosion of terrace and upland areas. Marsh lands in the study area have a higher percentage of sand-size sediment 
than do the tidal flats. This is because of their location in interdune or near beach enviroments. Considerable amounts of organic material are common in these sediments, and inter-stratified with them.

$\underline{\text { Soi1 }}$

Soils in these wetlands are commonly more than 60 inches $(1.5 \mathrm{~m})$ deep, and classified as loamy fine-sands, silty clay-loam, or siltyclay. Pockets of peat occur locally.

Hydrologic Properties

Deposits in these areas have poor drainage. They have low or very low permeability, and there are usually few outlets for ground water drainage. Because of these factors, the ground water table is near, at, or above the surface throughout the year.

\section{Engineering Qualities}

Extremely wet conditions hamper use of equipment in these landforms, but dredging is sometimes possible. The organically-rich sand, silt, and clay is highly compressible (CBR 5 - 17) and unsuitable for most foundation types. Pre-loading, piling, or rock-fill is usually necessary

\section{MARINE TERRACES}

When discussing the geological and engineering characteristics of the marine terraces, it is important to note that the underlying terrace platform (see Fig. 3) can be formed of sedimentary or igneous material. The engineering and geologic conditions of both platform 
types are discussed below.

\section{Rock Type}

Terrace Cover Deposits. The cover deposits are made up of flatlying, semi-consolidated to unconsolidated, angular to rounded quartzofeldspathic silts and sands; with lenses or laminae of heavy, sand-size minerals occurring 1ocally. One to two foot $(0.3$ to $0.6 \mathrm{~m})$ thick, subparallel layers of argillaceous sands are common, and high energy deposits of gravel and cobble material occur locally.

Volcanic Terrace Platforms. These features are common in the headland areas, and can be made up of sub-aerial, submarine, or intrusive basaltic material. The sub-aerial and intrusive rocks are common1y quite dense, but have well developed joint surfaces. The submarine deposits are commonly highly fractured and brecciated with occasional well developed pillow structures.

Sedimentary Terrace Platforms. The sedimentary terrace platforms are made up of a variety of materials of the A1sea, Yaquina, Nye, and Astoria Formations (see section on geologic history). Of primary importance to planning is the heterogeneous nature of the deposits, the interbeds of ash and other argillaceous material, and the westerly dipping nature of the bedding planes in most sedimentary terrace platforms.

$\underline{\text { Soi1 }}$

Soils are commonly developed only on the terrace cover deposits. They are usually more than 60 inches $(1.5 \mathrm{~m})$ deep, and classified as loams, fine-sandy-1oam, silt-loam, or clay-loam. These soil classifications are dependent on the percent of fines in the parent material. 


\section{Hydrologic Properties}

Terrace Cover Deposits. These materials are in a good drainage class. They have moderate to moderately low permeability depending on the percent of fines, and they are usually well drained. These deposits are not commonly thick enough to provide ground water reservoirs.

Terrace Platforms. Both the volcanic and sedimentary platform rocks are in a poor drainage class. They are frequently highly impermeable. As a result, ground water reaching the contact between the platform and the overlying deposits must move along the contact, or along zones of weakness (i.e., bedding planes, joints, fractures) in the platform materials.

\section{Engineering Qualities}

Terrace Cover Deposits. These unconsolidated materials are easily excavated with a bulldozer blade, but slopes greater than 15 to 20 percent are subject to mass wasting or rapid erosion if not adequately supported and protected. They are fairly compressible (CBR 8 - 17) but will support light structures if adequate spread footings are used.

Terrace Platforms. These features are commonly buried and not encountered in engineering activities. Detailed information on the engineering qualities of the sedimentary and igneous rocks that make up these platforms is contained in the sections pertaining to the geologic and engineering characteristics of the uplands and basaltic headlands respectively. At this point, however, it is important to note that these platform materials are prone to failure along bedding planes, joints, or fractures - especially if these surfaces have been 
undercut by excavation or erosion, or saturated by ground water.

\section{BASALTIC HEADLANDS}

\section{Rock Type}

The basaltic headlands in the study area are made up of columnarjointed sub-aerial basalt flows and intrusive basalt, as well as highly fragmenta1, brecciated submarine basalt flows and pillows.

$\underline{\text { Soil }}$

Soils on basaltic headlands have depths ranging from 0 to 40 inches ( 0 to 1 meter) and are classified as silty-clay, silty-clay-loam, or grave11y-1oam.

\section{Hydrologic Properties}

Soils. Where soils exist, their hydrologic properties vary considerably because of the variation of parent material. Drainage is good to excessive, and permeability is low to high. Both of these characteristics are directly related to the percentages of gravel and fines in the soil.

Bedrock. The bedrock material is commonly impermeable except along joints, fractures, or inter-flow zones.

\section{Engineering Qualities}

Soils. The shallow soils on the basaltic headlands can be easily excavated with a bulldozer blade. Compressibility is variable (CBR 8 45) and nearly al1 of these soils are subject to various forms of mass wasting - soil creep, sliding, slump, rockfall - because of their situation on steep slopes. 
Bedrock. The dense sub-aerial or intrusive basalt commonly requires blasting for excavation, whereas the fractured or brecciated material usually requires only bulldozer ripping. Both types of material will hold slopes of one to one, but unsupported slopes are subject to mass wasting because of failure of the rock along joints, fractures, or flow contacts.

These materials are limited in their foundation suitabilities by their susceptibility to mass wasting, and by the steep slopes commonly associated with them.

VI. UPLANDS

\section{Rock Type}

The upland areas consist of a complex variety of marine sediments and volcanics of the Nestucca, Astoria, Nye, Yaquina, and Alsea Formations. These are primarily sandstones, siltstones, and mudstones with interbedded volcaniclastic and organic material. Interbedded subaerial and submarine basalt flows, as well as basic intrusive rocks, are common throughout the Coast Range uplands. The distribution, composition and origin of these rocks is described by Snavely and Wagner (1973); and Snavely, MacLeod, and Wagner (1972).

$\underline{\text { Soil }}$

Upland soils are commonly more than 60 inches $(1.5 \mathrm{~m})$ deep, and are classified as silt, silty-clay, or silty-clay-loam. Dense, forest root networks are also typical.

\section{Hydrologic Properties}

Soils. The upland soils are characterized by fairly good drain- 
age. They have moderate permeability, and medium to slow runoff.

Bedrock. The bedrock materials are nearly impermeable. Ground water movement is primarily restricted to the bedding plane surfaces, or along zones of structural weakness.

\section{Engineering Qualities}

Soil. Upland soils are easily excavated with a bulldozer blade, but their great depths, fairly high clay content, and steep slope locations make them prone to mass wasting. They are quite compressible (CBR 7 - 8) but will support low load structures on gentle slopes.

Bedrock. Bedrock material in the upland areas commonly requires ripping by bulldozer for excavation. Slopes up to one to one are fairly stable except when dipping bedding planes are undercut on the down dip direction.

Foundation suitabilities are limited by susceptibility to mass wasting and steep slopes. 
CHAPTER V

GEOLOGIC PROCESSES OF POTENTIAL HAZARD TO MAN

In the coastal area, where the energy of the sea strikes the land, geologic processes are extremely active, and often violent. When man or his works conflict with these natural processes, a hazard to man often results. Man and his works may also endanger the natural system, but this section considers those potential hazards to man which exist in each of the coastal landforms. Of primary concern are slope instability, sea-cliff retreat, flooding by rivers, tide, or sea waves, and surficial erosion.

Early settlers in the coastal environment learned by experience to build their homes and businesses in areas not subject to these hazards, and they established communities on the relatively safe marine terraces. More recent development, however, has occurred in less suitable areas. The increasing demand for vacation residences, and the growing tourist population have made view lots near the sea-cliff or on the forested upland area extremely valuable. Undeveloped homesite lots in these areas are currently selling for prices from $\$ 5,000$ to $\$ 20,000$ or more each. Although potentially hazardous conditions vary from area to area, it seems ironic that the most valuable real estate is often also the most hazardous.

For general purposes, beaches, active dunes, and headlands can be considered the most hazardous landforms; and uplands, marshes and tidal flats can be considered moderately hazardous. Least hazardous, if de- 
veloped properly, are marine terraces and stabilized dunes. No landform is so forgiving that it can be developed upon without a full understanding of the natural conditions related to it.

\section{BEACHES}

Hazards to individuals on the beach include waves, rip currents, rolling drift logs, and sea-cliff collapse. There is little that can be done to avoid such hazards, except to inform the public with instructive signs located in the hazardous areas.

Houses or other structures in the beach zone may be struck by storm or earthquake generated (tsunami) waves, hit by drift logs and beach rocks, or be undermined or buried by fluctuations in beach sediment transport. Sea walls or bank protections rob the beach of its sediment source and normal operating area, and thereby result in accelerated sediment erosion in other areas. Private land development in the beach zone restricts public access, and attempts to protect or preserve these private beaches may destroy the aesthetic values for which the area was first developed. An example of the hazards which result from man's attempt to encroach upon the active beach zone is shown in Figure 13.

Development of active beach areas should be completely avoided. Any structures, modifications, or development in the beach zone requires determination of the total balance of processes operating on that beach, and this information is just not presently available. Erosion to supply beach sediment is a natural beach process that must be respected and preserved. 


\section{ACTIVE DUNES}

Active dunes are a very low hazard landform, except when attempts are made to inhibit the freedom of the dune sands to shift. Permanent structures such as houses, commercial buildings, and transportation facilities are not compatible with sand movement, which causes undermining or burial, and if situated on or near active dunes are also subject to sand blasting by wind-carried sediment. Artificial stabilization of the dunes results in the interruption of dune processes, the results of which are not yet clearly understood. Active dunes should be left undeveloped since no modification or developments are known which are compatible with dune processes.

\section{STABILIZED DUNES}

Stabilized dunes have potentially hazardous conditions similar to those of active dunes. They are subject to rapid erosion and reactivation if their protective vegetation and soil cover is removed. Should reactivation occur, the dunes develop those hazardous conditions discussed in the previous section on active dunes. Cooper (1958) shows excellent photographic evidence of the reactivation of stabilized dunes.

Because of the high permeability of stabilized dune sands, they are not adequate for septic drain field use. Introduction of sewage into these sands will result in pollution of the ground water table, and hence, destruction of a potential water supply reservoir.

These hazardous conditions are not severe enough to prevent the development of stabilized dunes by man. In fact, many of the coastal 
towns are built on these landforms; but it is important that future stabilized dune development be controlled by detailed land use planning. Adequate controls should be developed and strictly imposed.

\section{MARSH LANDS AND TIDAL FLATS}

Constant susceptibility to flooding, poor foundation characteristics, and the chance of losing valuable natural resources are the most potentially hazardous conditions associated with this landform type. Development in the large estuarine tidal flats has been limited by recent recognition of the necessity to preserve these vital landforms, but the smaller stream mouth and interdune areas are still being developed with complete disregard for natural processes. A condominium development was recently constructed around the mouth of Little Creek [ two miles $(3.2 \mathrm{~km})$ north of Newport] despite the imminent danger of wave damage, stream flooding, foundation failure, and landsliding (from the surrounding terrace slopes), (see Fig. 14). In addition, the construction of any type of structure on or around these landforms deprives the public of access to them, degrades their aesthetic value, and threatens the loss of their tremendous contribution to the coastal environment. Tidal flats and marsh lands are limited in number, and they serve an important purpose in their natural state.

\section{MARINE TERRACES}

The marine terrace, if properly developed, is the most hazardfree (and also the most common) landform in the study area. Preservation of the vegetative cover, and adequate spacing of septic facilities are necessary to avoid hazardous conditions. If the unconsolidated 
terrace cover material becomes exposed to erosive processes, steep walled gully erosion will develop and continue to expand if not controlled by replacement of vegetation or construction of artificial drainage routes. Construction of too many septic drain fields (approximately more than one per acre - depending on soil analysis) could result in pollution of terrace ground water and streams that eventually reach the beach recreation area, and finally the sea.

Cliffs in the terrace materials, especially if they are subject to wave attack, are very hazardous. Homes or other structures constructed near these cliffs are subject to undermining and eventual destruction (see Figs. 15 and 16). The unconsolidated terrace cover material is easily eroded by wind or wave abrasion, or the exposed cliff face may become so saturated by ground water, sea spray, and/or rain that the low cohesive strength of the unconsolidated sediments will no longer support the load. The result is a peeling off of a portion of the cliff face that may be over a foot thick. The terrace platform (Tertiary basaltic or sedimentary material) exposed in a cliff face is also subject to erosion by wave abrasion, or by failure along saturated joint surfaces, fractures, or dipping bedding planes.

Marine terrace sea-cliffs are also subject to episodic large scale failure that may affect the terrace up to several hundred feet back from the cliff edge (see Fig. 17). Appendix B contains further information on the rates of sea-cliff retreat.

The marine terraces do provide a relatively safe site for man's occupation, providing density of residences is controlled, and all cliffs, gullies, and areas adjacent to them are avoided. 
VI. BASALTIC HEADLANDS

The hazardous conditions of the headlands of Cape Foulweather, Yaquina Head, and Seal Rocks are rock fall, rock slide, landslides, soil creep, and the very rugged, steep topography. The headlands are beautiful landforms that, to date, have not been subjected to developmental pressures. Because of this, their hazards have been limited to rocks crashing down onto the beach, or, not infrequently, the falling of inexperienced or unwary climbers from the cliffs. Any attempt to develop structures on these landforms would encounter the very active hazardous conditions of mass wasting mentioned above.

Hazards on the basaltic headlands are so numerous, and the aesthetic qualities of their natural state so valuable, that they should be left as natural as possible so that their rugged, awe-inspiring beauty is preserved.

\section{UPLANDS}

The processes of mass wasting and rapid surficial erosion create potential hazards in the upland areas. Like the basaltic headlands, the upland areas have not yet undergone extensive development; but as population increases, the resultant demand for permanent and vacation residences has inspired developers to begin moving up onto the upland slopes.

The results of uncontrolled development of this landform would create numerous hazards. Unrestricted removal of the vegetative cover would result in rapid erosion of exposed surficial materials. This, in turn, would result in the gullying of hillsides, undercutting of 
foundations, siltation of streams and estuaries, and a destruction of the aesthetic values so necessary to the local economy. Undercutting of dipping bedding planes or clay rich layers could instigate major mass wasting that could be highly destructive in a developed area. Finally, the covering of precipitation absorbing surfaces with houses, roads, parking lots, and other structures would increase and channel runoff, and thus, accelerate erosion.

A great majority of these hazards could be avoided by the adoption of land use planning that required a geological investigation of every proposed development site. This type of planning for the upland areas, and other problematic landforms as well, will mean the difference between the instigation of hazardous and costly conditions, or the development of safe, multi-use landforms that could enhance the beauty of the coastal area. 


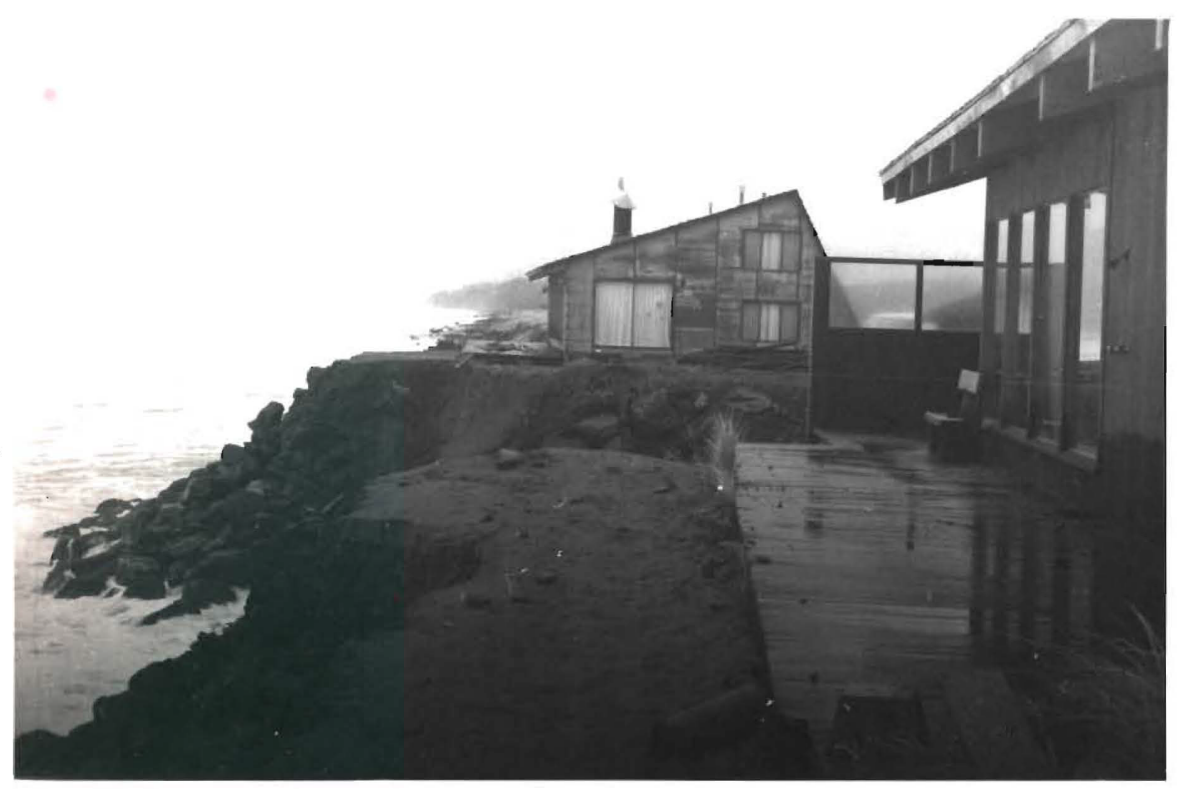

Figure 13. Erosion of beach sand at Salishan Spit - Damage of man made structures resulted from erosion of over 75 feet of material along portions of the spit in January, 1973.

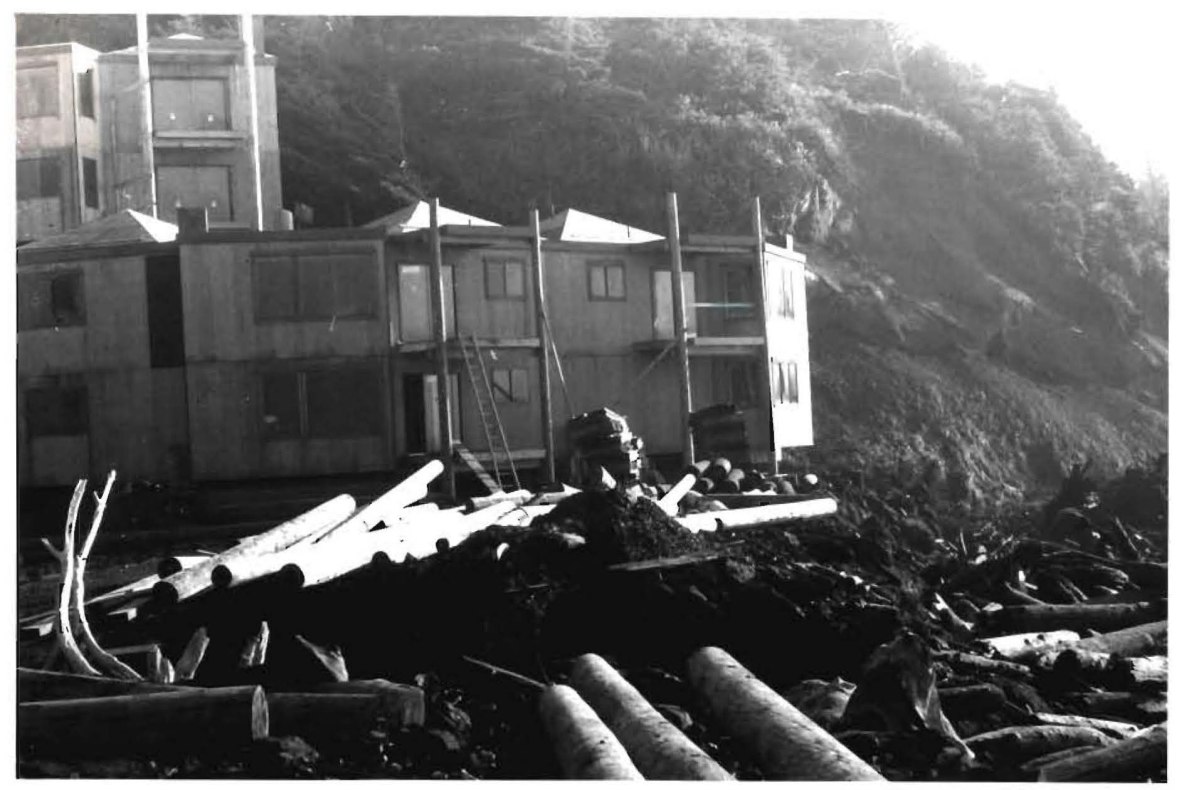

Figure 14. Condominium units constructed around the mouth of Little Creek despite numerous potentially hazardous conditions. 


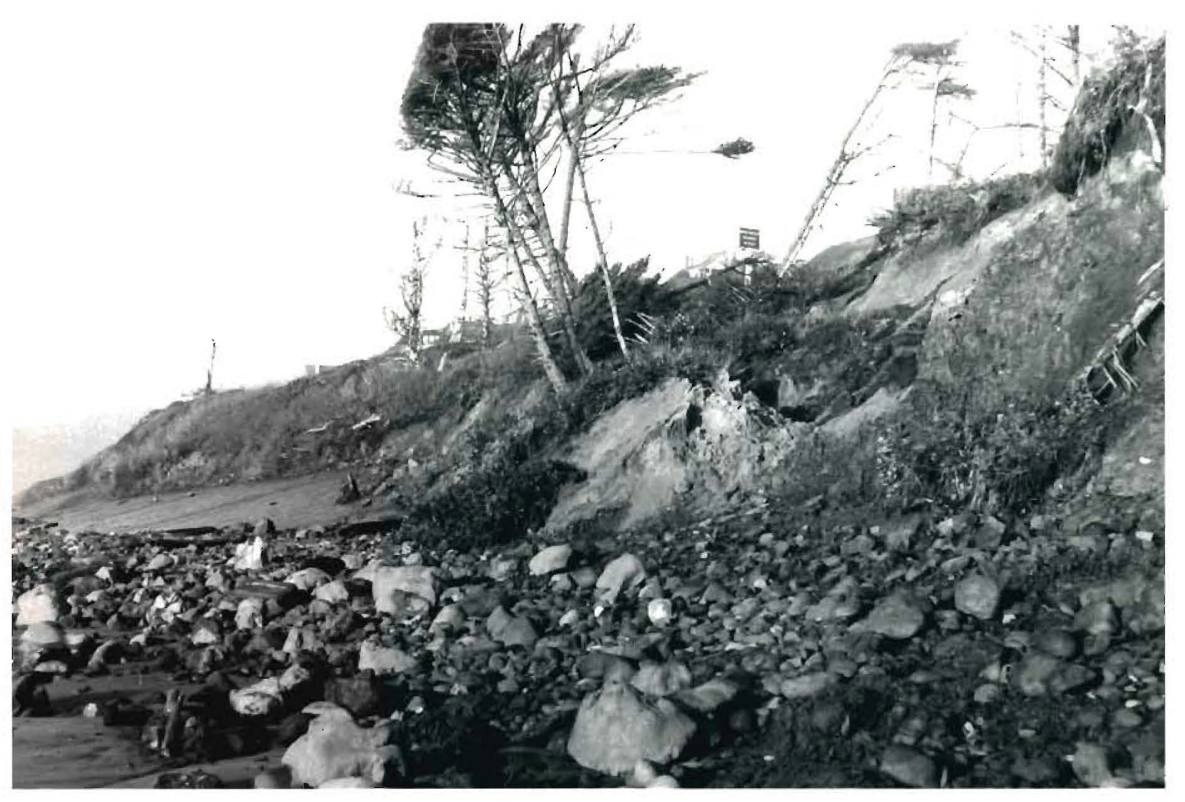

Figure 15. Erosion of marine terrace materials exposed in the sea-cliff near Moloch Beach, 1.5 miles north of Yaquina Head.

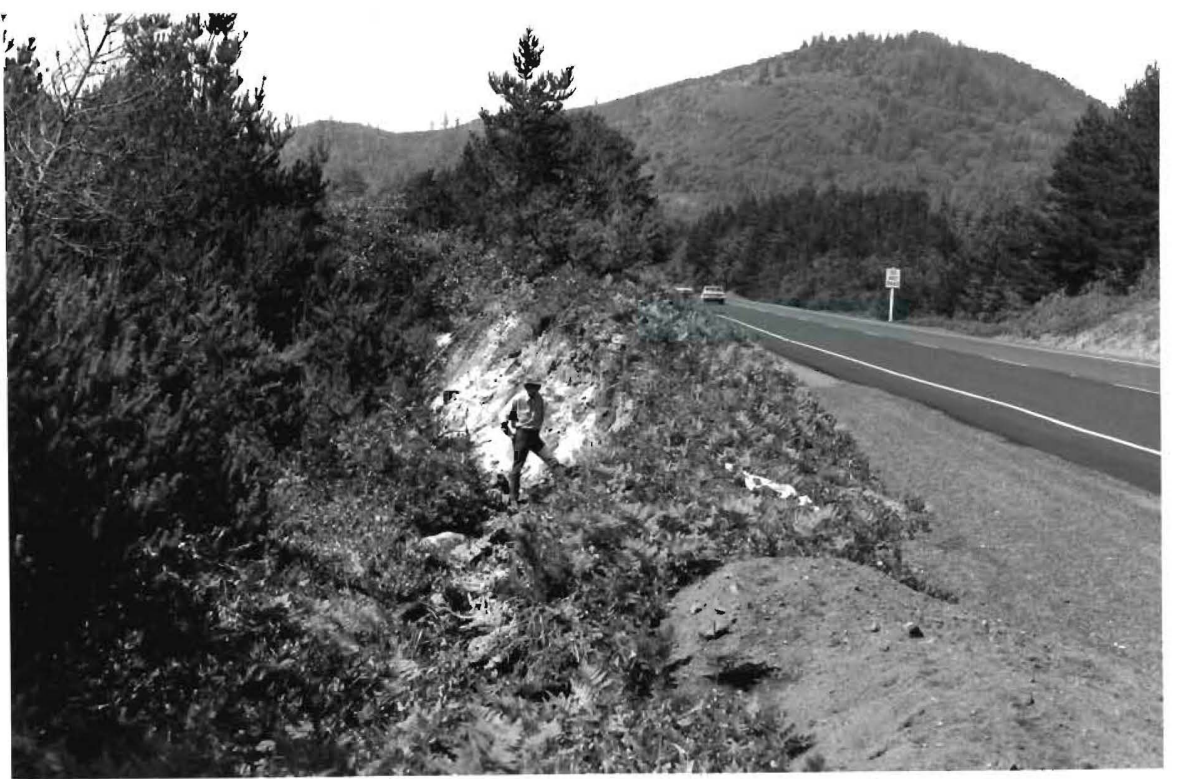

Figure 16. Landslide scarp resulting from failure of marine terrace materials and dipping Astoria Formation one mile south of Otter Rock. Highway 101 (right side of photograph) was damaged by this slide and required repaving. 


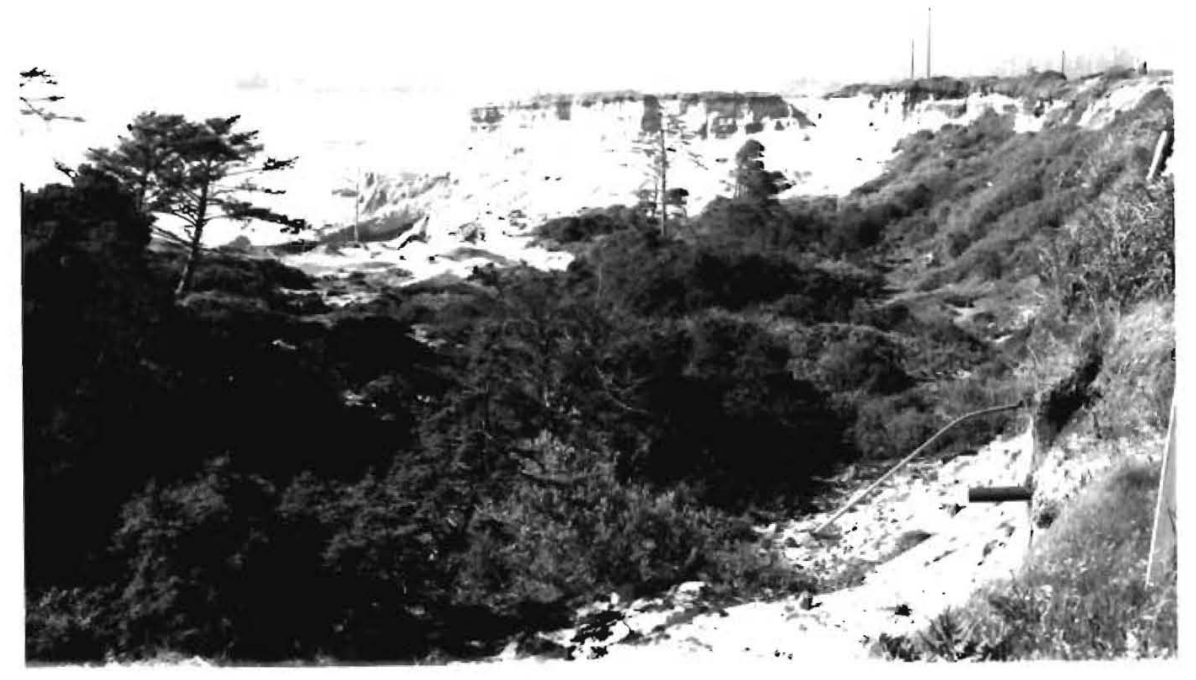

Figure 17. Terrace sea-cliff landslide at Jump off Joe - one half mile north of Newport.

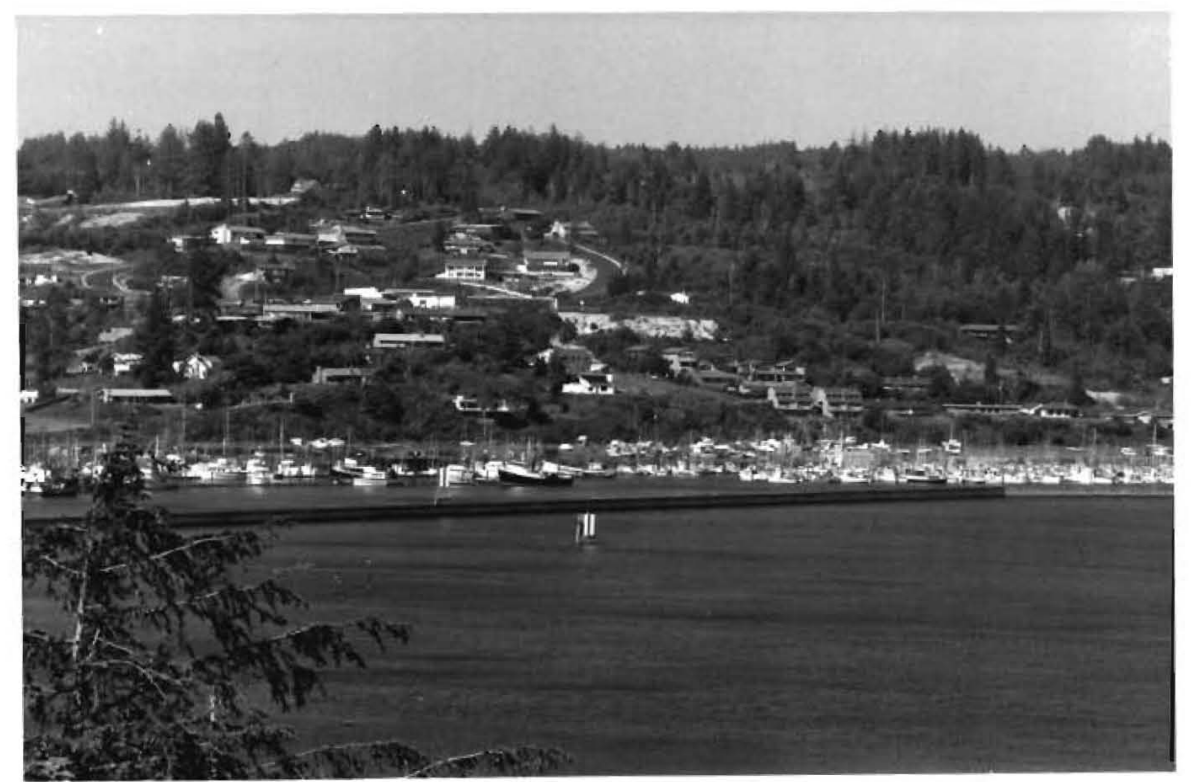

Figure 18. Population pressures are resulting in increased development in the potentially hazardous foothills of the upland areas. 


\title{
CHAPTER VI
}

\author{
SUITABILITY FOR RESIDENTIAL OR \\ LIGHT-COMMERCIAL DEVELOPMENT
}

Developmental pressures in the coastal area are strongest for residential and light-commercial (motels, apartments, restaurants, service stations, gift shops, and other similar structures) purposes. The material discussed in the preceding sections, and the maps (Figs. 19, 20, and 21) are herein used to develop a land use suitability map for residential and 1 ight-commercial development, of the study area. The method used to develop the land use map was somewhat similar to methods described by McHarg (1971) and Meyers (1972) in that it involved the construction of overlay maps, each pertaining to a single land use characteristic. In this evaluation, the overlay maps pertained to slope, soils, and geologic hazards. Each of the overlay maps was shaded to show those portions of the study area that were considered acceptable for development, unacceptable for development, or questionable. Figures 19,20 , and 21 are copies ( $\frac{1}{2}$ original size) of the overlay maps used to evaluate slope, soils, and geologic hazards, respectively. These three overlay maps were placed, one atop the other, on a light table, and the resulting shade patterns were used to make a summary evaluation map showing five categories of development suitability for the study area (Fig. 26). These five categories showed the degree of acceptability for development, in all three factors (slope, soils, and geologic hazards) for the entire study area. The following pages con- 
tain more detailed descriptions of the suitability evaluation and summary maps. These maps are for regional planning only; more detailed site evaluations are necessary for individual projects.

\section{SLOPE}

The slope evaluation map (Fig. 19) was developed from field data and information provided by the Lincoln County Soil Conservation Service. For planning purposes, the study area was divided into three slope groups. Zero to 12 percent slopes were left unshaded and termed acceptable for development. Twelve to 20 percent slopes were shaded gray and termed questionable (the questionable classification indicates that an area can be acceptable, but only if land use planning in regard to the natural conditions is used). Those areas with slopes greater than 20 percent were shaded black and termed unacceptable for developmental purposes (development in certain unacceptable areas may be possible, but would require extensive pre-development investigation, potentially prohibitive developmental costs, and could create hazardous conditions).

\section{SOILS}

Five soil factors which are directly related to problems common to residential and light-commercial development were used in evaluating (evaluation based on information provided by the Lincoln County office of the U.S. Soil Conservation Service) the suitability of the various soil series in the study area (see Fig. 20). These factors were: depth, susceptibility to flooding, shrink-swell potential, erosion 


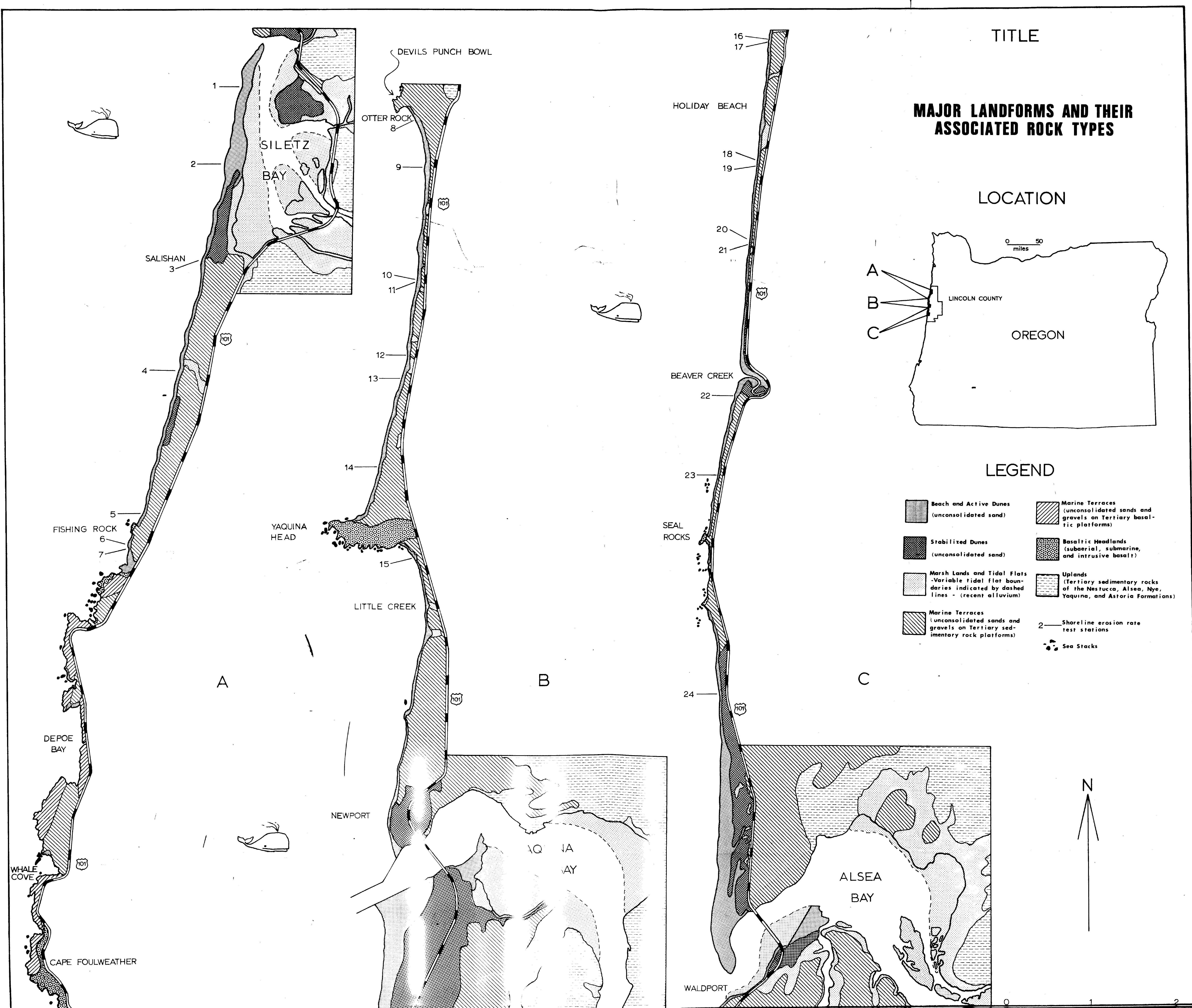


hazard, and septic tank drain field limitations. Soils that were unacceptable in any of the five factors were shaded black and termed unacceptable. Soils that were acceptable in all five factors were termed acceptable, and not shaded. Detailed information on the various soil factors can be found on the legend of Fig. 20 and in Appendix A.

\section{GEOLOGIC HAZARDS}

Factors evaluated on this map (Fig. 21) were landslide potential, rate of sea-cliff retreat (see Appendix B), surficial erosion rates, and foundation suitability. Development of this map was based primarily on field data, with supplementary information taken from Schlicker and others (1972), the Oregon State Water Resources Board (1969), and the Portland Cement Association (1962).

Those portions of the study area where erosional or instability problems are common, or where foundation capabilities are not adequate for one to three story structures were termed unacceptable, and shaded black. Those areas which experience few stability or erosional problems, and that have adequate foundation capabilities were termed acceptable and not shaded.

IV. DEVELOPMENT SUITABILITY EVALUATION - SUMMARY

The evaluation summary map (Fig. 26) is a summary of the information represented on Figures 19,20 and 21 . The relative suitability, for residential or light-commercial development of various portions of the study area are indicated by degree of shading. Those portions which are most suitable are left unshaded, and as suitability decreases the amount of shading increases. Finally, those areas which are least 


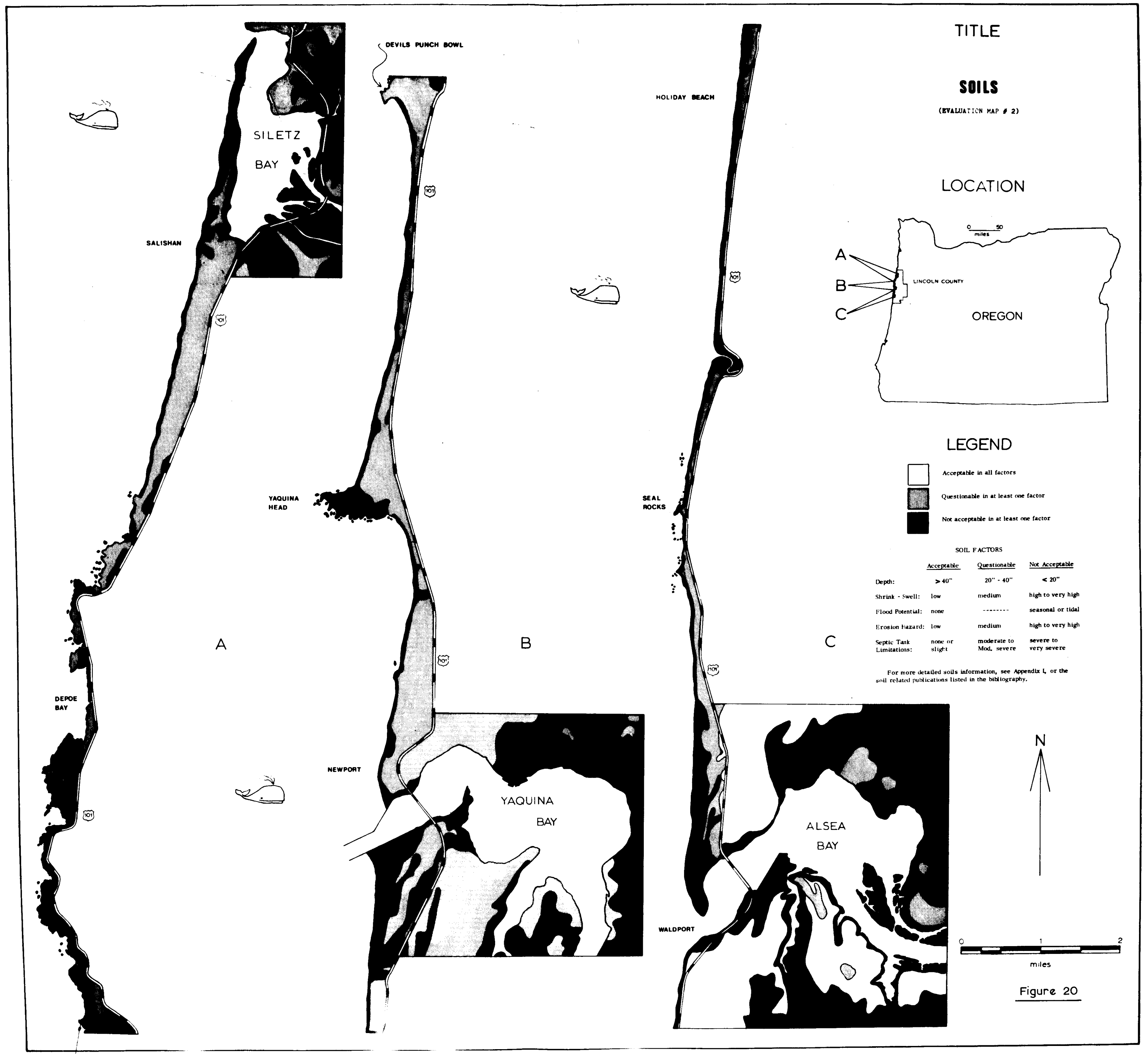




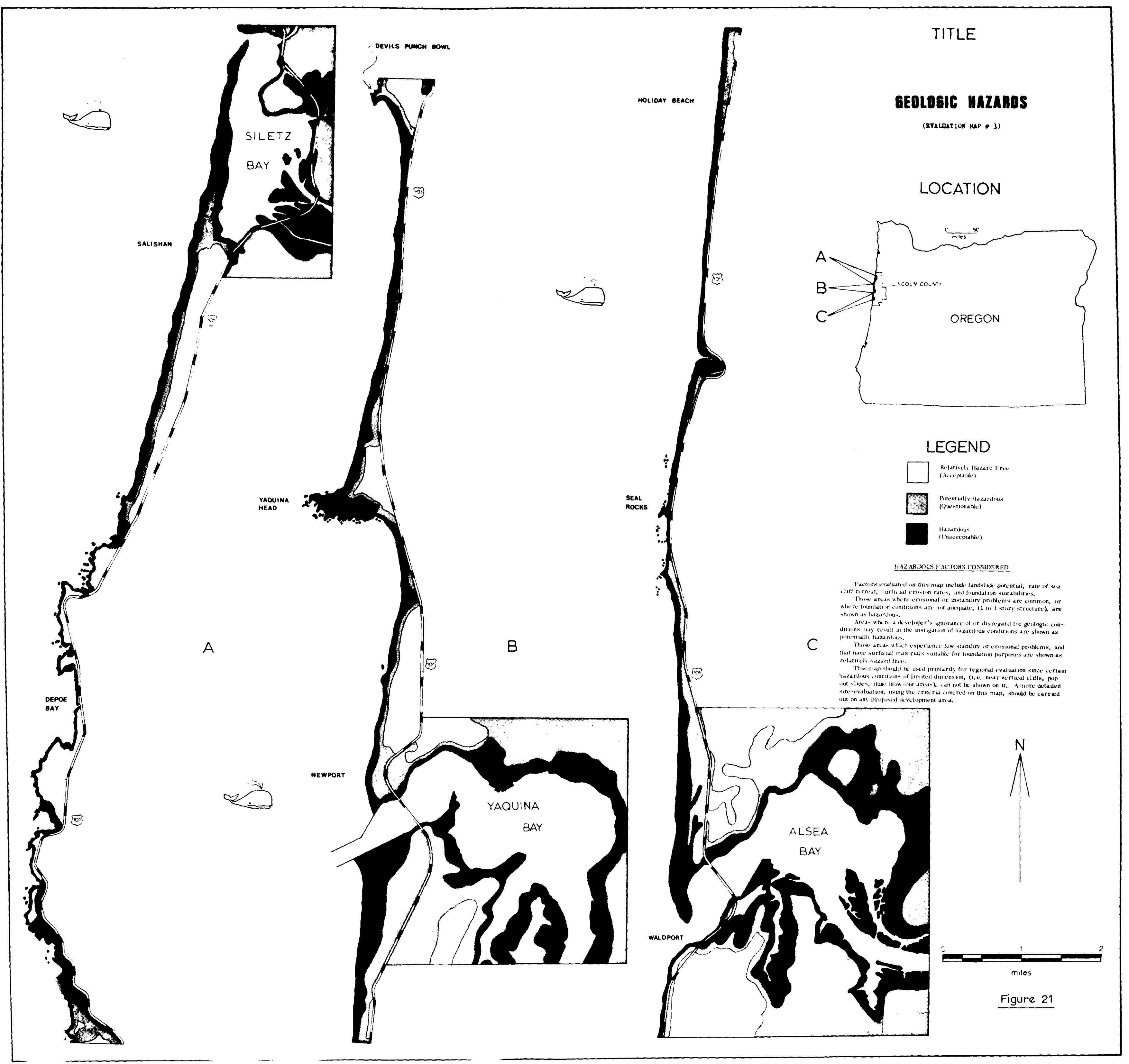


suitable are shown as black.

It is important to note that this map is not aimed at totally preventing development in certain areas, but rather at insuring that development in all areas is beneficial to the total coastal environment. Those areas shown as less suitable should not be considered offlimits to development; but it should be recognized that they will require more critical evaluation by qualified experts to determine if development should be permitted, and if so, under what conditions. 
CHAPTER VII

SUMMARY AND RECOMMENDATIONS

The study area, a section of Oregon's beautiful coast line, is made up of seven major landform types. Each of these landform types can be described and evaluated on the basis of a variety of factors, such as physical characteristics, geologic and engineering characteristics, and occurrence of potentially hazardous processes. An understanding of these factors provides the best means of determining the land use suitability of the coastal area, and thereby insuring the protection and preservation of this valuable natural environment.

The text, appendices, and maps of this report contain descriptions and evaluations of those landform factors mentioned above. It is recommended that this information be used in forming guidelines and objectives for future coastal developmental planning, and for guiding decision-making on current coastal planning problems.

It is further recommended that construction and development criteria related to the specific problems and processes of the coastal area be developed, and presented in the form of building code legis1ation. In addition to defining these criteria, this legislation should specify the need for verification by qualified experts of the safety and enviromental compatibility of any proposed development.

This type of legislation, if enacted and applied, would insure that future coastal development would be in the best interest of safety, natural aesthetic quality, and economic security. 
Allen, J. E., and Baldwin, E. M., 1944, Geological and coal resources of the Coos Bay quadrangle. Oregon: Oregon Dept. of Geol. and Mineral Indus. Bull. 27, 160 p.

Baldwin, E. M., 1945, Some revisions of the late Cenozoic stratigraphy of the southern Oregon coast: Jour. Geol. 53, p. 34-46. 1959, Geology of Oregon: Eugene, University of Oregon Cooperative Book Store, $164 \mathrm{p}$.

Bascom, Willard, 1964, Waves and beaches, the dynamics of the ocean surface: New York, Doubleday and Co., Inc., 267 p.

Beaulieu, J. D., 1971, Geologic formations of western Oregon, west of longitude 1210 30': Oregon Dept. Geol. and Mineral Indus. Bull. $74,164 \mathrm{p}$.

Bird, E. C. F., 1969, Coasts: Cambridge, Mass., M.I.T. Press, 246 p.

Bureau of Governmental Research and Service, 1969, The central Oregon coast, physical conditions and present development: University of Oregon, Bureau of Governmental Research and Service, 50 p. 1969, The central Oregon Coast, population and housing: University of Oregon, Bureau of Governmental Research and Service, 29 p.

Cooper, W. S., 1958, Coastal sand dunes of Oregon and Washington: Geol. Soc. America Memoir 72, 169 p.

Dole, H. M., 1954, The Astoria landslide: Ore Bin, v. 16, no. 1, p. 1-2.

Griggs, A. B., 1945, Chromite-bearing sands of the southern part of the coast of Oregon: U.S. Geol. Survey Bull. 945-E, p. 113-150.

Lund, E. H., 1972, Coastal landforms between Yachats and Newport, Oregon: Ore Bin, v. 34, no. 5, p. 73-91.

McCurdy, P. G., 1947, Manual of coastal delineation from aerial photographs: U. S. Navy Hydrographic Office, Pub. No. 592, 143 p.

McHarg, I. L., 1969, Design with nature: Garden City, N.Y., Natural History Press, 197 p.

Meyers, Joseph, 1972, Personal communication.

North, W. B., and Byrne, J. V., 1965, Coastal landslides of northern Oregon: Ore Bin, v. 27, no. 11, p. 217-241.

Oregon State Water Resources Board, 1969, Oregon's Iong range requirements for water: Oregon State Water Resources Board app. I-1, 17 , and $18,83 \mathrm{p}$. 
Palmer, L. A., 1967, Marine terraces of California, Oregon, and Washington: University of California at Los Angeles, Doctoral Dissertation, $379 \mathrm{p}$.

Pattulo, J. G., Burt, W. V., and Burdwell, G. B., 1968, Tsunami on the Oregon coast from an earthquake near Japan: Ore Bin, v. 30, no. 9, p. 182-184.

Plafker, George, 1972, Alaskan earthquake of 1964, and Chilean earthquake of 1960: implications for arc tectonics: Jour. Geophys. Research, v. 77, no. 5, p. 901-925.

Portland Cement Association, 1962, P.C.A. soil primer: Chicago, I11., Portland Cement Assoc., 52 p.

Schlicker, H. G., Corcoran, R. E., and Bowen, R. G., 1961, Geology of the Ecola State Park landslide area, Oregon: Ore Bin, v. 23, no. 9, p. 85-90.

Schlicker, H. G., Deacon, R. J., Beaulieu, J. D., and 0lcott, G. W., 1972, Environmental geology of the coastal region of Tillamook and Clatsop counties, Oregon: Oregon Dept. Geol. and Mineral Indus. Bull. 74, $164 \mathrm{p}$.

Shepard, F. P., and Wanless, H. R., 1971, Our changing coastlines: New York, McGraw Hill Book Co., 579 p.

Smith, W. D., 1933, Physiography of the Oregon coast: Pan Amer. Geol., v. 59, p. 92-114.

Snavely, P. D., Jr., and MacLeod, N. S., 1971, Visitor's guide to the geology of the coastal area near Beverly Beach State Park, Oregon: Ore Bin, v. 33, no. 5, p. 85-105.

Snavely, P. D., Jr., MacLeod, N. S., and Rau, W. W., 1969, Geology of the Newport area, Oregon: Ore Bin, v. 31, no. 2 and 3, p. 25-71.

Snavely, P. D., Jr., MacLeod, N. S., and Wagner, H. C., 1972a, Preliminary bedrock geologic map of the Cape Foulweather and Euchre Mountain quadrangles, Oregon: U.S. Geol. Survey open-file map.

1972b, Preliminary bedrock geologic map of the Waldport and Tiucwater quadrangles, Oregon: U.S. Geol. Survey open-file map.

$19 \% 2 \mathrm{c}$, Preliminary bedrock geologic map of the Yaquina and Toledo quadrangles, Oregon: U.S. Geol. Survey open-file map.

Snavely, P. D., Jr., Rau, W. W., and Wagner, H. C., 1964, Miocene stratzeraphy of the Yaquina Bay area, Newport, Oregon: Ore Bin, v. 26 , no. 8, p. 133-151. 
Snavely, P. D., Jr., and Wagner, H. C., 1963, Tertiary geologic history of western Oregon and Washington: Washington Division of Mines and Geol. Rpt. Invest. 22, $25 \mathrm{p}$.

Snavely, P. D., Jr., and Volkes, H. E., 1949, The coastal area between Cape Kiwanda and Cape Foulweather, Oregon: U.S. Geol. Survey Oil and Gas Invest. Map OM-97.

U.S.D.A. Soil Conservation Service, 1971, Aerial photographs of portions of the Lincoln County coast with soil series boundaries outlined: Lincoln County Soil Conservation Service, Unpublished Data. various dates, Soil interpretations: OR-1 series: U.S.D.A. Soil Conservation Service Soil Interpretation Sheets.

Volkes, H. E., Norbisrath, Hans, and Snavely, P. D., Jr., 1949, Geology of the Newport - Waldport area, Lincoln county, Oregon: U.S. Geol. Survey Oil and Gas Invest. Map OM-88. 


\section{APPENDIX A}

\section{SOILS INFORMATION}

A complete understanding of the five to ten feet of surface material is perhaps the most valuable tool available to land use planners. With the exception of mining, well drilling, tunneling, and a few other subsurface activities, most of man's interaction with the earth takes place in this uppermost layer of soils and subsoils. Soils in varying localities, and even associated soil horizons (Fig. 22) are by no means homogeneous. They may vary considerably in grain size, clay content, compaction, etc., and it is these variations in the soil parameters that define the suitabilities of soils for various uses. As more and more surface area is lost to random development, it becomes extremely critical to define those soil areas that are still undeveloped, and insure that they are utilized for the purposes to which they are best suited.

The soil series names and descriptions of the 22 soils shown on the soil series map (Fig. 27) were taken directly from the State Water Resources Publications (1969) or from Lincoln County Soil Conservation Service soil description and suitability charts. The soil series boundarias shown on Fig. 27 were taken in part from information plotted on black and white air-photographs by the Lincoln County S. C. S. Mapping in areas where S. C. S. soil series boundary information was not available was done by field interpretation, and the association of certain soil series with characteristic physiographic localities. 


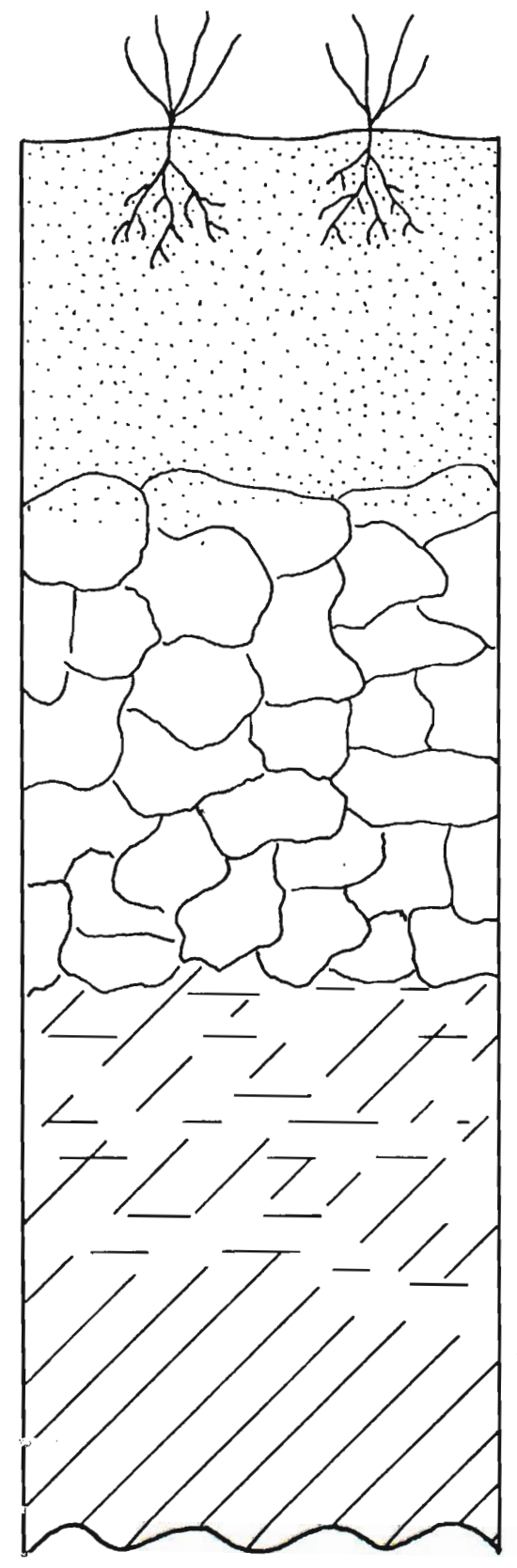

Organic accumulation, eluviation, and maximum leaching.

A

Horizon

$B$

Horizon

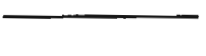

Slightly weathered and altered parent material.

C

Horizon

Parent material.

Redeposition of material leached from A horizon, illuviation, clay accumulation--this horizon commonly has a blocky or prismatic structure.

Bedrock

Figure 22. Soil Horizon diagram. 
Table I is a soils information chart that lists the 22 soil series common to the study area. It also shows their association with various landform types, and lists several characteristics of the soils which may be valuable to land use planners. Definitions of the soil evaluation characteristics 1 isted in Table $I$ are contained in the following pages. These definitions are (except where otherwise noted) taken from the Oregon State Water Resources Board (1969).

\section{SOIL EVALUATION CHARACTERISTICS}

\section{Percent Slope}

Numbers in percent slope column of Table I (0-3, 3-7, etc.) indicate the range of percent slope with which the soil series is commonly associated. Several soil series are common on a wide range of slopes.

\section{$\underline{\text { Soi1 Depth }}$}

This column gives the depth range in inches of the $\mathrm{A}, \mathrm{B}$, and $\mathrm{C}$ horizons of the various soil series.

\section{Texture}

Several soil texture classification systems are available. The chart lists the textural breakdown of the $A, B$, and $C$ horizons of each soil series, based on one of the most commonly used soil classification systems: the Unified Soil Classification System (UNI). The major divisions, group symbols, and typical names of soils as classified under this system are shown in Figure 23. Descriptions of this and other soil classification systems are contained in the Portland Cement Association Soil Primer (1962) and in soil science texts. 


\begin{tabular}{|c|c|c|c|c|}
\hline \multicolumn{3}{|c|}{ Major Divisions } & $\begin{array}{l}\text { Letter } \\
\text { Symbol }\end{array}$ & Typical Descriptions \\
\hline \multirow{8}{*}{$\begin{array}{l}\text { Coarse } \\
\text { grained } \\
\text { soils }\end{array}$} & \multirow{4}{*}{$\begin{array}{l}\text { Gravel } \\
\text { and } \\
\text { Gravelly } \\
\text { soils }\end{array}$} & \multirow[t]{2}{*}{$\begin{array}{l}\text { Clean Gravels } \\
\text { (little or no } \\
\text { fines) }\end{array}$} & GW & $\begin{array}{l}\text { Well-graded gravels, gravel- } \\
\text { sand mixtures, little or no } \\
\text { fines. }\end{array}$ \\
\hline & & & GP & $\begin{array}{l}\text { Poorly-graded gravels, } \\
\text { gravel-sand mixtures, little } \\
\text { or no fines. }\end{array}$ \\
\hline & & \multirow{2}{*}{$\begin{array}{l}\text { Gravels with } \\
\text { fines (appre- } \\
\text { ciable amount of } \\
\text { fines) }\end{array}$} & GM & $\begin{array}{l}\text { Silty gravels, gravel-sand- } \\
\text { silt mixtures. }\end{array}$ \\
\hline & & & GC & $\begin{array}{l}\text { Clayey gravels, gravel-sand- } \\
\text { clay mixtures. }\end{array}$ \\
\hline & \multirow{4}{*}{$\begin{array}{l}\text { More than } 50 \% \text { of } \\
\text { coarse fraction } \\
\text { passing No. } 4 \\
\text { sieve-- }(4.76 \mathrm{~mm})\end{array}$} & \multirow{2}{*}{$\begin{array}{l}\text { Clean Sand } \\
\text { (little or no } \\
\text { fines) }\end{array}$} & SW & $\begin{array}{l}\text { Well-graded sands, gravelly } \\
\text { sands, little or no fines. }\end{array}$ \\
\hline & & & SP & $\begin{array}{l}\text { Poorly-graded sands, grav- } \\
\text { elly sands, little or no } \\
\text { fines. }\end{array}$ \\
\hline & & \multirow{2}{*}{$\begin{array}{l}\text { Sands With Fines } \\
\text { (appreciable } \\
\text { amount of fines) }\end{array}$} & SM & $\begin{array}{l}\text { Silty sands, sand-silt mix- } \\
\text { tures. }\end{array}$ \\
\hline & & & $\mathrm{SC}$ & $\begin{array}{l}\text { Clayey sands, sand-clay mix- } \\
\text { tures. }\end{array}$ \\
\hline \multirow{6}{*}{$\begin{array}{l}\text { More than } \\
50 \% \text { of ma- } \\
\text { terial is } \\
\text { smaller } \\
\text { than ivo, } \\
200 \text { sieve- } \\
\text { size -- } \\
(.074 \mathrm{~mm}) .\end{array}$} & \multirow[t]{3}{*}{$\begin{array}{l}\text { Silts } \\
\text { and } \\
\text { Clays }\end{array}$} & \multirow[t]{3}{*}{$\begin{array}{l}\text { Liquid Limit } \\
\text { less than 50* }\end{array}$} & MIL & $\begin{array}{l}\text { Inorganic silts and very } \\
\text { fine sands, rock \& flcur, } \\
\text { silt or clayey fine sands or } \\
\text { clayey silts with slight } \\
\text { plasticity* }\end{array}$ \\
\hline & & & CL & $\begin{array}{l}\text { Inorganic clays of low to } \\
\text { medium plasticity, gravelly } \\
\text { clays, sandy clays, silty } \\
\text { clays, lean clays. }\end{array}$ \\
\hline & & & $\mathrm{OL}$ & $\begin{array}{l}\text { prganic silts and organic } \\
\text { silty clays of low plasti- } \\
\text { city. }\end{array}$ \\
\hline & \multirow{3}{*}{$\begin{array}{l}\text { Silts } \\
\text { and } \\
\text { Clays }\end{array}$} & \multirow{3}{*}{$\begin{array}{l}\text { Liquid Limit } \\
\text { greater than } \\
50\end{array}$} & $\mathrm{MH}$ & $\begin{array}{l}\text { Inorganic silts, micaceous or } \\
\text { diatomaceous fine sand or } \\
\text { silty soils. }\end{array}$ \\
\hline & & & $\mathrm{CH}$ & $\begin{array}{l}\text { Inorganic clays of high plas- } \\
\text { ticity, fat clays. }\end{array}$ \\
\hline & & & $\mathrm{OH}$ & $\begin{array}{l}\text { prganic clays of medium to } \\
\text { pigh plasticity, organic } \\
\text { pilts. }\end{array}$ \\
\hline \multicolumn{3}{|c|}{ Highly Organic Soils } & $\mathrm{PT}$ & $\begin{array}{l}\text { Peat, humus, swamp soils } \\
\text { With high organic contents. }\end{array}$ \\
\hline
\end{tabular}

* Liquid Limit and Plasticity are engineering characteristics of fine grained soils that are determined by laboratory methods.

Figure 23. Unified Soil Classification System -- soil texture chart. 


\section{Permeability}

The soil permeability is a measure of the range of water flow through a unit cross-section of saturated soil per unit of time. The permeability of a soil is determined by its least permeable layer. Soil permeability is important to the planner for determining erosion potential, and septic drain field capabilities of a soil. The permeability terms used in Table I are defined as follows:

\begin{tabular}{ll} 
Relative rate & Rate in inches pe \\
\cline { 2 - 2 } very slow & 1 ess than 6 \\
slow & $0.06-0.20$ \\
moderately slow & $0.21-0.63$ \\
moderate & $0.64-2.00$ \\
moderately rapid & $2.01-6.30$ \\
rapid & $6.31-20.0$
\end{tabular}

\section{$\underline{\text { Runoff }}$}

Five classes of runoff are recognized on the basis of the relative rate at which water is removed from the soil by flow over the surface. Runoff rates depend on the soil slope, texture, infiltration rate, plant cover, and intensity of rainfall. Runoff rates are important for determining erosion potential. Definitions of the five classes are as follows:

Very Slow. Surface water flows away very slowly, and free water either covers the surface for long periods of time or enters almost immediately into the soil. Most of the water either passes through the soil or evaporates from the surface. Soils with very slow runoff rates are usually nearly level to slightly concave, or have rapid infiltration rates.

Slow. Surface waters flow away so slowly that free water covers 
the surface for significant periods of time or enters quite rapidly into the soil. Much of the water either passes through the soil or evaporates from the surface. Soils with slow rates of surface runoff are usually nearly level or have moderate to rapid infiltration rates.

Medium. Surface water flows away at such a rate that a moderate amount of water falling on the surface enters the soil profile and free water covers the soil surface only for short periods. A large part of the precipitation is absorbed by the soil.

Rapid. Surface water flows rapidly over the soil surface and a small amount enters the soil and moves through the profile. Soils with rapid rates of runoff are usually moderately steep to steep, or have moderate to slow infiltration rates.

Very Rapid. Surface water flows rapidly over the soil surface and only a very small amount enters and moves through the soil. Surface water runs off as fast as it falls on the soil. Soils with very rapid rates of runoff are either very steep or have slow to very slow infiltration rates or both.

\section{Effective Root Zone}

This classification should not be confused with soil depth. The effective root zone, like soil depth, can be determined by depth to bedrock, but it can also be determined by depth to a very permeable or impermeable layer in the soil horizon. The effective root zone deternimes the ssil's ability to sustain vegetation and kbsurb precipitation, and as a result, is a factor in the soil's susceptibility to erosion. Effective root zones in Table I are listed in inches. 


\section{Acidity}

The acidity of the $A, B$, and $C$ horizons was listed in Table I. if the information was available. The acidity of the soil has an effect on vegetation growth, and can affect any objects (cables, pipes, foundations) buried in the soil horizon. The relative acidity terms used in Table I and their $\mathrm{pH}$ values as defined by the U. S. Soil Conservation Service are listed below:

\begin{tabular}{ll} 
Relative Acidity & \multicolumn{2}{c}{-Value } \\
\hline neutral & $7.3-6.6$ \\
low & $6.5-6.1$ \\
moderate & $6.0-5.6$ \\
strong & $5.5-5.1$ \\
very strong & $5.0-4.5$ \\
extreme & 1 ess than 4.5
\end{tabular}

\section{Available Water Holding Capacity}

This is a measure of the total water available in the upper 60 inches ( 1.5 meters) at capacity. It is important to vegetation growth and to determining mass wasting potential and foundation capability. The five categories and their values in inches are as follows:

$\begin{array}{ll}\text { Category } & \text { Available Water (in inches) } \\ \text { very high } & \text { more than } 12 \\ \text { high } & 9-12 \\ \text { moderate } & 6-9 \\ \text { low } & 3-6 \\ \text { very low } & \text { less than } 3\end{array}$

\section{Shrink-Swe11 Potential}

This is a relative measure of volume change with changing moisture content. Soils with a high shrink-swell potential will tend to decrease in volume when dry, and increase in volume when wet. The relative categories indicated in Table I are low, medium, and high. 
Soils with a high shrink-well potential tend to be unstable on moderate to steep slopes, and are not usually adequate for fill or foundation material.

\section{$\underline{\text { Drainage Class }}$}

Drainage classes for the various soils indicate the degree of soil wetness under natural conditions. The determining factors include amount of water available, soil permeability, and number of ground water outlets for permeable zones. This is a very important factor for determining foundation capability, septic drain field suitability, and mass wasting potential. Soils that are not in good drainage classes are commonly not adequate for foundation or septic purposes, and are prone to mass wasting on steep slopes. The five drainage classes and their definitions are as follows:

Excessive. Root zone saturation extremely rare.

Good. Root zone saturation only during brief periods - no surface standing water.

Somewhat Poor. Intermediate between good and poor.

Poor. Water table at or near surface for a considerable part of the year.

Very Poor. Water table at or near the surface practically constant $1 y$.

Possibility of Flooding

The possibility of flooding is based on records of past flooding activicy and the relation of a soil to a possible flood-water source. The four categories 1 isted in Table I are tidal, seasonal, occasional, 
and none. The definitions of these categories are as follows:

Tida1. This category includes those areas subject to flooding from daily or seasonal tidal fluctuations.

Seasonal. Soils in the seasonal category are subject to flooding anywhere from several times a year to once every five years.

Occasional. These areas are subject to flooding, but commonly less than once every five years.

None. These areas are not expected to be subject to flooding.

\section{$\underline{\text { Erosion Hazard }}$}

The soil erosion hazard is an estimation of how susceptible the soil is to erosion when the surface is left bare. It is a function of soil slope, texture, organic matter content, infiltration rates, and intensity of precipitation. This classification is important when considering effects of vegetation removal. The relative categories used in Table I are: low, medium, high, and very high. The protective vegetation cover on soils with medium, high, or very high ratings should not be unnecessarily removed.

\section{Ease of Excavation}

Soil materials are easily excavated with a bulldozer blade, but the different parental rock materials associated with the soils have varying hardness, density, and structural characteristics, and as a result, require different means of excavation. Ease of excavation is an important factor in determining foundation suitability and developitient costs. The three categories of excavation methods and their definitions, based on personal field observations and experience, are 
as follows:

Blade. Unconsolidated, highly brecciated, or poorly indurated materials can usually be removed by the use of a bulldozer blade.

Rip. Well indurated sedimentary rocks or highly fractured or jointed igneous rocks commonly require bulldozer ripping for excavation.

Blast. Dense, hard igneous rocks commonly require dynamite blasting for excavation.

Septic Tank Drain Field Limitation

The degree of limitation for drain fields of septic systems depends primarily on wetness, permeability, depth, and slope of the soil. The best soils for septic systems are level, permeable, and welldrained. They are not subject to floods, and they do not overlie open, gravelly material which would allow contamination of the ground water. Four degrees of limitation: slight, moderate, severe, and very severe, are indicated in Table I. In order to insure satisfaction of public health standards, specific area limitations for septic purposes should be determined by the federal, state or county organizations having jurisdiction over the issuing of septic drain field permits.

\section{California Bearing Ratio}

The California Division of Highways developed a method for testing the load bearing capacity and compressibility of various materials. In this test, materials are subjected to a load pressure while being conined.. Their reaction to the load is then compared to the reaction of a "standard" well-graded gravel to the same load. On the basis of 
this comparison, the material being tested is assigned a load bearing value (ranging from 0 to 100) commonly referred to as its CBR value. High CBR values indicate an ability to support heavy loads while undergoing very little compression. Low CBR values indicate highly compressible materials with low load-support capacity. The approximate CBR values in Table I were taken from the PCA Soil Primer (1962). More detailed information on the California Bearing Ratio can be found in a variety of engineering publications and reports, including Schlicker and others (1972). 
TABS I

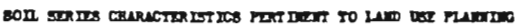

\begin{tabular}{|c|c|c|c|c|c|c|c|c|c|c|c|c|c|c|c|c|c|c|c|c|c|c|c|c|}
\hline & \multirow[t]{2}{*}{$\begin{array}{l}\text { PEIS 100PAVI } \pi \\
\text { PCE:T10K }\end{array}$} & \multirow[t]{2}{*}{ son } & \multirow{2}{*}{$\begin{array}{l}8 \\
6 \\
3 \\
\end{array}$} & \multirow{2}{*}{ 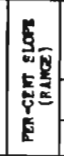 } & \multicolumn{3}{|c|}{$\begin{array}{l}\text { son LePRE } \\
\text { (10 1mches) }\end{array}$} & \multicolumn{3}{|c|}{ 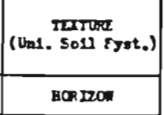 } & \multirow[t]{2}{*}{ 点 } & \multirow{2}{*}{ E } & \multirow{2}{*}{$\begin{array}{l}5 \\
8 \\
8 \\
8\end{array}$} & \multirow[t]{2}{*}{ 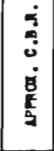 } & \multicolumn{3}{|c|}{ MCR } & \multirow{2}{*}{$\begin{array}{l}\dot{4} \\
\dot{4} \\
\dot{a} \\
\dot{i}\end{array}$} & \multirow[t]{2}{*}{ 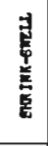 } & \multirow[t]{2}{*}{ 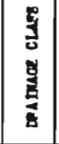 } & \multirow[t]{2}{*}{ 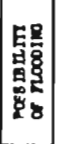 } & \multirow{2}{*}{ 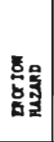 } & \multirow[t]{2}{*}{ 害 } & \multirow[t]{2}{*}{ 带量 } \\
\hline & & & & & $\Delta$ & B & c & 4 & - & $\mathbf{c}$ & & & & & $\Delta$ & B & c & & & & & & & \\
\hline \multirow{2}{*}{\multicolumn{2}{|c|}{ ETUSY Am I IDUL ARUS }} & Coquill. & co & $0-3$ & $0-13$ & $13-60$ & $40-6 n$ & $a$ & $\underset{C L}{C L}$ & CI & $\begin{array}{l}=\infty-1 \\
\Rightarrow \rightarrow 00\end{array}$ & 10 & $20-20$ & $e$ & -ir. & itr. & izr. & $\bmod$ & 200 & poor & isines & 200 & P & $\therefore$ \\
\hline & & Iidel Net. & If & $0-3$ & $!^{\prime}$ & 1 & l & $m$ & $\bar{z}$ & $m$ & -20 & poend & 10 & 100 & \begin{tabular}{|l|} 
etr. \\
\end{tabular} & etr. & intr. & I & 200 & poor & ersel & 200 & $\mathbf{P}$ & $\dot{m}$ \\
\hline \multirow{4}{*}{ 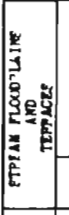 } & Lact & $2030=0 x$ & $a$ & $0-7$ & $0-27$ & $17-60$ & $20-60$ & 4 & $\begin{array}{l}a \\
c L\end{array}$ & . & $\infty$ & 0100 & 10 & 8 & ret. & . & I & bigh & $20+$ & $\infty$ & cosea & 200 & 2 & $\infty$ \\
\hline & $\begin{array}{l}3 \\
2 \\
8\end{array}$ & Nentuces & 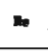 & $0-7$ & $0-16$ & $2<-6]$ & $\Delta-60$ & $x$ & cL & $\underset{H}{C H}$ & $\infty$ & $=100$ & 60 & 8 & itr. & itr. & etr. & hest & 100 & Door & mencis & ond & ) & net \\
\hline & ? & Bremer & or & $0-3$ & $0-13$ & $|13-22|$ & $21-8$ & m. & $c_{C 2}^{a}$ & ct: & - 100 & ano & $20-20$ & 8 & otr. & etr. & $\infty$ & $\infty$ & sed & 2000 & \begin{tabular}{|l|} 
moner \\
ondind
\end{tabular} & 200 & B & $\therefore$ \\
\hline & TERFACE & Krappe & $r_{2}$ & $0-25$ & $0-16$ & $\mid 16-40$ & $48-6 n$ & ac & $\frac{M}{C L}$ & $\mathrm{CL}_{\mathrm{L}}$ & ond & $-1=$ & 60 & 8 & mir. & -itr. & .tr. & bigt & 100 & 8000 & $\propto<=$ & 100 & r & $218 \mathrm{~b}$ \\
\hline & RSCET & Dure Land & Ad & $2-35$ & $0-2$ & I & 1 & I & 1 & 1 & rap1d & $\because 0$ & 60 & 30 & I & I & I & ion & 100 & $\cos$ & noos & higb & $B$ & $\therefore$ \\
\hline & & Sand Benct & sb & $0-7$ & I & I & I & I & 1 & 1 & repid & -ion & I & 30 & I & I & 1 & $\therefore$ & 100 & 1000 & eiden: & nist & B & in \\
\hline & & & w⿰ & $n-7$ & $0-13$ & $|23-52|$ & $52-$ & sw . & su & sy & rapld & -isos & 60 & 17 & ntr. & etr. & etr. & 100 & 100 & 10000 & - & Ind & B & $\infty+\infty$ \\
\hline 案 & & Metart. & $n$ & $7-12$ & $0-13$ & $|13-52|$ & $52-$ & sm & sy & s! & rap10 & $=100$ & 60 & 17 & atr. & enr. & etre. & 100 & 100 & 2000 & nose & ned- & $\mathbf{P}$ & mod \\
\hline E & OUER & & $r$ & $12-35$ & $0-23$ & $|13-52|$ & $52-$ & su & su & sI & rep10 & .100 & 60 & 17 & rer. & istr. & etr. & 100 & 100 & 3000 & none & net & $\mathbf{P}$ & mov \\
\hline 㝨 & & Goerhart & $O_{n}$ & $0-7$ & $0 \rightarrow 8$ & $\mid 8-30$ & 38- & sy & 5x & $\varepsilon x$ & rep 10 & in & 60 & 17 & atr. & $=\infty$ & and & 100 & 100 & 2000 & nom & $=\infty$ & B & \begin{tabular}{|l|} 
nod \\
ner
\end{tabular} \\
\hline & & bornete & $G_{D}$ & $7-35$ & $0-8$ & $8-36$ & -8- & Ex & su & sy & rapid & $\therefore$ & 60 & 27 & atr. & $=\infty$ & $=\infty$ & 100 & 200 & 2000 & nome & b1eb & D & $\bmod$ \\
\hline & INTEP $\rightarrow$ DURI & Yoqus ne & ye & $0-?$ & $n-6$ & $6-30$ & $30-62$ & sm & Ex & $s p$ & repid & $\therefore$ & $60-60$ & 17 & itr. & etr. & etr. & 100 & 200 & Door & onan & - & B & mor \\
\hline & Low dores & Merrestun & we & $0-7$ & $0-3$ & $3-20$ & $20-50$ & 54 & sy & $\begin{array}{l}\text { Sp } \\
\text { six }\end{array}$ & repse & $\therefore$ & 60 & 17 & otr. & etr. & rer. & 100 & 200 & poor & $\mid \begin{array}{l}\text { soen } \\
\text { onel }\end{array}$ & b1gh & B & net \\
\hline & & & $F_{0}$ & $3-7$ & $0-22$ & $|22-41|$ & $41-68$ & CL & su & sin & $\operatorname{cod}$ & .200 & $10-60$ & 17 & etr. & 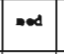 & $\infty \infty$ & $\infty$ & 200 & 6000 & none & 200 & B & plight \\
\hline & $5 S: D Y$ & Ferrelo & $F_{n}$ & $7-12$ & $0-22$ & $|22-42|$ & $41-68$ & $\frac{m}{c L}$ & su & su & $=\infty$ & .100 & $40-60$ & 27 & str. & mod & $\bmod$ & $-\infty$ & 100 & cood & none & $=\infty$ & P & - $\infty$ s \\
\hline & & & 7. & $12-20$ & $0-22$ & $22-41 \mid$ & $\omega-6 B$ & $\mathrm{cL}_{\mathrm{CL}}$ & sy & su & $=\infty$ & $=\infty$ & $40-60$ & 17 & ntr. & med & $\infty$ & $\infty$ & 100 & 8000 & sone & $=\infty$ & B & not \\
\hline 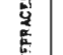 & & & the & $0-3$ & $0-22$ & $12-4$ & $\underset{120}{42-}$ & $a_{\text {cL }}$ & CL & $\begin{array}{l}\mathrm{SC} \\
\mathrm{CL}\end{array}$ & $\bmod _{\min }$ & slom & 60 & $6-10$ & itr. & etr. & atr. & bregt & 100 & 8000 & none & 100 & D & -od \\
\hline 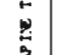 & & & $M_{n}$ & $3-7$ & $0-12$ & $22-46$ & $\frac{4-}{120}$ & $\frac{\mathrm{MC}}{\mathrm{CL}}$ & CL & $\begin{array}{l}\mathrm{sc} \\
\mathrm{cL}\end{array}$ & 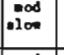 & .100 & 60 & $8-10$ & etr. & etr. & etr. & b10t & 100 & 8000 & mone & 100 & B & \begin{tabular}{|l|}
$\infty \infty$ \\
$\infty$
\end{tabular} \\
\hline 3 & Lon: & Nel acot: & Ne & $7-22$ & $0-12$ & $22-46$ & 420 & CL & CL & $\begin{array}{l}c c \\
C L\end{array}$ & $\begin{array}{l}\operatorname{lod} \\
-100\end{array}$ & $=100$ & 60 & $8-20$ & otr. & etr. & etr. & hiet & 100 & 8000 & nome & -od & D & $\begin{array}{l}\text { nod } \\
\text { ner }\end{array}$ \\
\hline & & . & m. & $22-35$ & $0-12$ & $12-46$ & 120 & $\frac{\mathrm{LI}}{\mathrm{CL}}$ & CL & $\begin{array}{l}S C \\
C L\end{array}$ & $=100$ & $=\infty$ & 60 & $0-20$ & etr. & itr. & otr. & brets & 100 & 2000 & none & h1th & B & $\infty$ \\
\hline & $\begin{array}{l}\text { LOMN OR SAKTI } \\
\text { I/ KLPDPAR }\end{array}$ & Depor & $D p$ & $0-3$ & $0 \rightarrow 7$ & $7-16$ & $16-33$ & $x$ & Cl & su & $=10$ & 020 & $|15-20|$ & $8-10$ & $\therefore$ ir. & itr. & ext & 200 & 100 & poor & none & 100 & B & nev \\
\hline & & Aetor 10 & $\Delta$ & $7-12$ & $0-19$ & $29-50$ & $30-68$ & $\mathbf{x}$ & CL & $\frac{M}{c L}$ & $=\infty$ & $010 \pi$ & 60 & 7 & itr. & itr. & itr. & bist & $\infty$ & $\cos$ & nom & $-\infty$ & $D / n$ & $\infty \infty$ \\
\hline & SEDTERAPY & & $\Delta$ & $12-60$ & $0-19$ & $19-50$ & $30-68$ & a & $\begin{array}{l}H \\
\mathrm{CL}\end{array}$ & $\frac{\mathrm{CC}}{\mathrm{CL}}$ & $=\infty$ & $-\infty$ & 60 & 7 & itr. & itr. & itr. & hiph & $=\infty$ & 1000 & mone & bigh & $B N$ & $=\infty$ \\
\hline & & Fendel & Id & $20-60$ & $0-12$ & $\mid 22-30$ & $30-58$ & CL & CL & $\begin{array}{l}2+1 \\
\mathrm{CL}\end{array}$ & $\operatorname{cod}$ & $-\infty$ & $20-40$ & 8 & itr. & itr. & $\infty x$ & $\bmod$ & $=\infty$ & 1000 & nome & b1st & $8 / n$ & in \\
\hline 8 & & Mowkon in & $\mathbf{m}$ & $12-60$ & $0-12$ & $12-27$ & 27- & $\frac{M a}{c L}$ & $\frac{a}{C L}$ & I & $\begin{array}{l}\operatorname{sod} \\
-100\end{array}$ & $-\infty$ & $20-40$ & 8 & etr. & itr. & I & $\infty$ & 100 & 2000 & nome & $-\infty$ & $m$ & $\therefore$ \\
\hline$\vec{B}$ & 厂" & Diek1tet & $\mathbf{n}$ & $20-90$ & $c-8$ & $0-47$ & 47- & ca & an & $!$ & $\mid \begin{array}{ll}\bmod \\
\operatorname{rap} 10\end{array}$ & $-\infty$ & $20-40$ & $\angle 5$ & etr. & its. & I & $\infty$ & 100 & $10 \infty$ & $\infty$ & ind/ & $D / n$ & in \\
\hline & 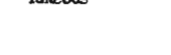 & Wueb1s & Kc & $=0-90$ & $0-5$ & $5-20$ & 1 & can & an & I & $\bmod _{\text {rap } 1 d}$ & repid & $|10-20|$ & 45 & etr. & itr. & 1 & 100 & 100 & exrees & nosos & 100 & $n / \infty$ & $\therefore$ \\
\hline & & 甘ebre & Bbo & $0-3$ & $0-12$ & $|22-44|$ & $\mu-$ & ac & $\frac{m}{c L}$ & / & $\infty$ & -10 & $50-60$ & 8 & etr. & itr. & I & breb & 100 & 8000 & noses & 200 & $8 / n$ & $\stackrel{\infty}{\infty}$ \\
\hline & 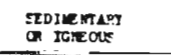 & Roekin nd & Nk & $20-90$ & $0-10$ & I & I & I & $1^{\prime}$ & 1 & ver1. & rep10 & $0-10$ & b1et & I & I & 1 & 100 & 100 & areos & & nerl. & $10 / 0$ & 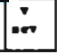 \\
\hline
\end{tabular}

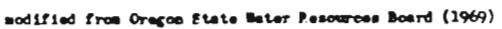




\section{APPENDIX B}

\section{SHORELINE EROSION RATES}

The shoreline in the study area is being eroded at different rates, and by different processes. In order to obtain a better understanding of the method and results of shoreline erosion, several bench mark stations were established and monitored over an eight month period from September 1972 to May 1973.

Three types of shoreline material were tested. These were: (1) the Tertiary bedrock sediments of the Astoria, Nye, Yaquina, and Alsea formations, (2) the unconsolidated to semiconsolidated sand, silt, and gravel that cap the marine terraces, and (3) the unconsolidated sands that comprise the recent active dune and beach features. Bench mark stations were not located on the volcanic headlands for two reasons. First of all, the hardness of the material would have made placement of a test station very difficult, and secondly, it was estimated that the short duration of the testing period would not have allowed adequate time for measurable results.

Three testing methods were employed. The first method involved the use of an erosion bench mark stake. The stake was an 18 to 24 inch $(45.7$ to $61 \mathrm{~cm})$ section of 0.375 inch $(0.95 \mathrm{~cm})$ concrete reinforcing steel that was driven into the face of sea-cliffs horizontally until oniy a few inches (several centimeters) remained exposed. The length of the exposed section was measured and recorded, and the test 
site indicated on a field map. In addition to the length of the exposed section, other pertinent information such as rock type, beach width, special features of the test site, and height of the station above the beach were recorded.

The second testing method was used in areas where the unconsolidated nature of the material involved would not allow the placement of a bench mark stake. The tests involved the marking and recording of the orientation and location of drift logs incorporated in the unconsolidated sand. This test was designed to determine if these logs and surrounding sand would be affected by wave action, rather than to gain quantitative information on erosion rates. Location of these test stations is shown in Fig. 28 .

In addition to the erosion stake and drift log stations, a series of photographic stations were established that may be helpful in monitoring long term shoreline variations. The original set of photographs, along with their locations and orientations, are on file in the Earth Science Library, Portland State University.

A11 of the bench mark stations were established on September 8 and 9, 1972. Measurements were taken and recorded on January 20 and 21, 1973 and on May 14 and 15, 1973.

The results of these tests led to the following four conclusions. (1) Although major sea-cliff retreat is episodic in nature, continual winter erosion takes place on all three types of material tested, and it is measurable, even over a relatively short period of time. Erosion or mass wasting of Tertiary sediments exposed in sea-cliffs is a result of direct wave abrasion. Landslides may occur when wave 
erosion undercuts a seaward dipping bedding plane. (3) Erosion of the terrace capping material occurs from direct wave abrasion, or when saturation of the terrace cliff face by ground water, rainfall, and sea spray causes the eventual peeling off of the saturated outer layer. (4) Beach and active dune features are truly mobile, and very susceptible to shoreline erosion processes.

The rate of shoreline erosion (Table II) is important not only because erosion is a hazardous condition to man, but also because it may play a necessary and critical role in the mechanism of sediment supply to the beach environment. (Hopefully, the information gained from these tests will be improved and expanded by further tests and data, in order to gain a more complete understanding of shoreline process rates).

\section{TEST RESULTS}

The average amount of erosion of unconsolidated terrace materials, based on test stations $3,4,5,11,13,17,19,20,22,23$, and 24 was 9.14 inches $(23.2 \mathrm{~cm})$ during the 250 day test period. The amount of erosion at each station is shown graphically in Figure 24, and 1isted in Table II.

The average amount of erosion of Tertiary bedrock sedimentary rocks, based on stations $6,7,8,9,10,12,14,15,16,18$, and 21 was 4.73 inches $(12.0 \mathrm{~cm})$ during the 250 day test period. The amount of orsion at each of the bedrock stations is shown graphically in Figure 25, and listed in Table II. 
These tests clearly show that sea-cliff retreat is a very active process along the entire seaward margin of the study area. A more intensive erosion monitoring program, using test methods similar to those described above and continued over a period of years, could provide information as to the relative susceptibility of the various rock units to wave erosion; and define, more clearly, those areas where sea-cliff retreat is most active. 


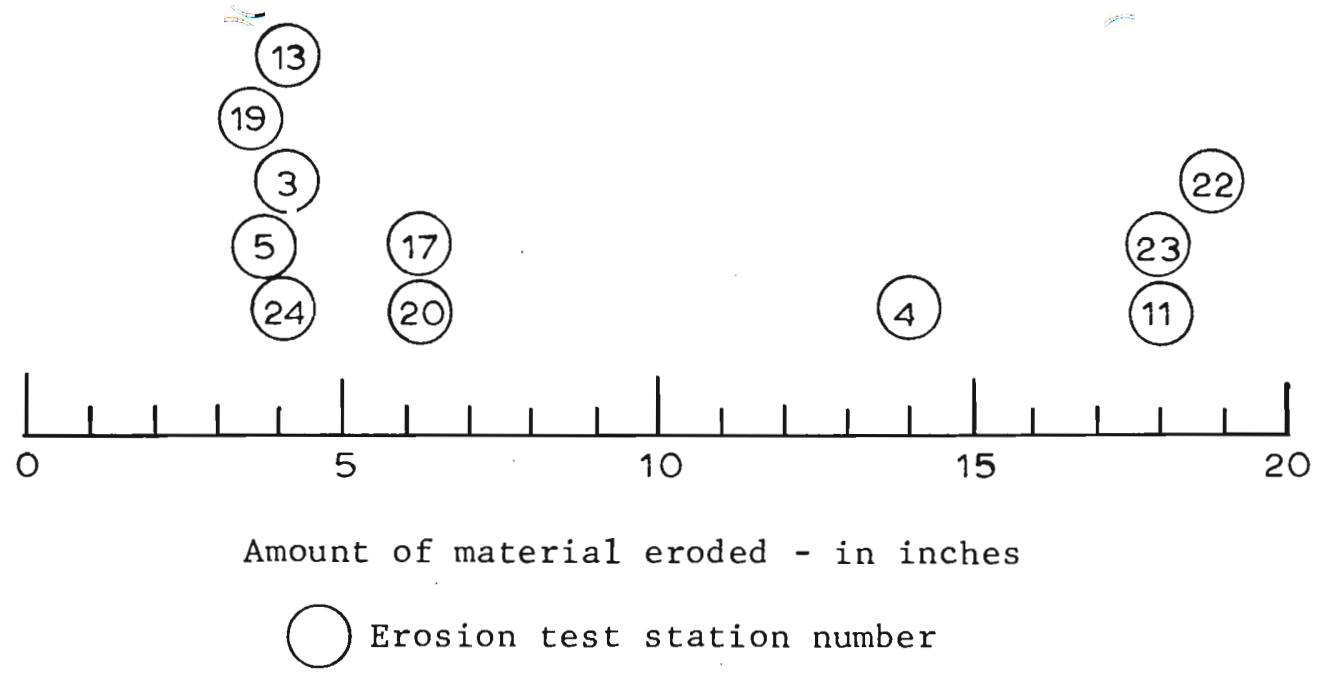

Figure 24. Erosion rate test results - unconsolidated marine terrace materials.

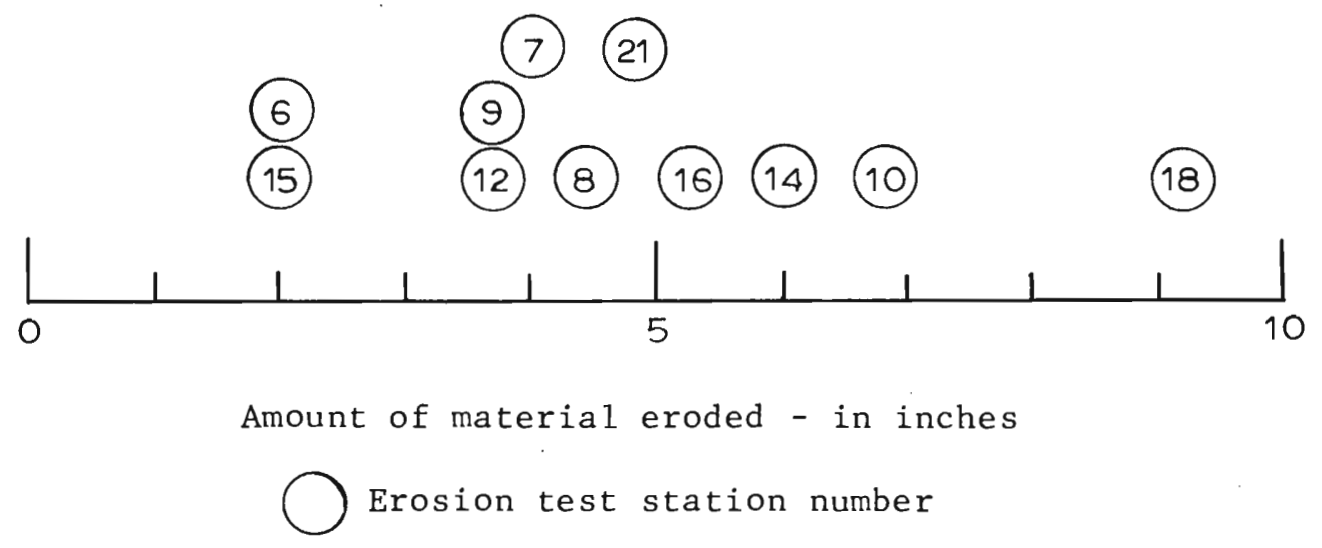

Figure 25. Erosion rate test results - Tertiary sedimentary rocks. 
TABLE 11

SHORELINE EROSION RATES - TEST DESCRIPTIONS AND RESULTS

\begin{tabular}{|c|c|c|c|c|c|c|}
\hline \multirow[t]{2}{*}{$\begin{array}{l}\text { Test } \\
\text { Station }\end{array}$} & \multirow[t]{2}{*}{$\begin{array}{l}\text { Type } \\
\text { of } \\
\text { Test }\end{array}$} & \multirow[t]{2}{*}{ Rock Type } & \multirow{2}{*}{$\begin{array}{l}\text { Approx. } \\
\text { Distance } \\
\text { From } \\
\text { Summer } \\
\text { Bern } \\
\end{array}$} & \multirow[t]{2}{*}{$\begin{array}{l}\text { Height } \\
\text { Above } \\
\text { Beach }\end{array}$} & \multicolumn{2}{|c|}{$\begin{array}{l}\text { Amount of matertal lost to } \\
\text { erosion during } 250 \text { day test } \\
\text { period }\end{array}$} \\
\hline & & & & & English & Metric \\
\hline$I$ & drift $\log$ & $\begin{array}{l}\text { unconsolidated sand } \\
\text { (Siletz Spit) }\end{array}$ & $200 \mathrm{ft}$ & $\cdots$ & \multicolumn{2}{|c|}{$\begin{array}{c}\text { log removed by storm } \\
\text { waves }\end{array}$} \\
\hline 2 & ." & $"$ & $"$ & $4 \mathrm{ft}$ & $76 \mathrm{ft}$ & $23.2 \mathrm{~m}$ \\
\hline 3 & $\begin{array}{l}\text { bench mark } \\
\text { stake }\end{array}$ & terrace sands' & $150 \mathrm{ft}$ & $40 \mathrm{ft}$ & $4.0 \mathrm{in}$ & $10.2 \mathrm{~cm}$ \\
\hline 4 & $"$ & $"$ & $250 \mathrm{ft}$ & $"$ & 14.0 in & $35.6 \mathrm{~cm}$ \\
\hline 5 & " & $"$ & $350 \mathrm{ft}$ & $7 \mathrm{ft}$ & 3.75 in & $9.5 \mathrm{~cm}$ \\
\hline 6 & $"$ & $\begin{array}{l}\text { massive siltstone } \\
\text { Astoria Formation }\end{array}$ & $50 \mathrm{ft}$ & $10 \mathrm{ft}$ & 2.0 in & $5.1 \mathrm{~cm}$ \\
\hline 7 & $\begin{array}{l}\text { bench mark } \\
\text { stake }\end{array}$ & $\begin{array}{l}\text { massive siltstone } \\
\text { Astoria Formation }\end{array}$ & $150 \mathrm{ft}$ & $6 \mathrm{ft}$ & 4.0 in & $10.2 \mathrm{~cm}$ \\
\hline 8 & $"$ & $\begin{array}{l}\text { highly fractured } \\
\text { sandstone, Astoria } \\
\text { Formation }\end{array}$ & $"$ & $4 \mathrm{ft}$ & $4.5 \mathrm{in}$ & $11.4 \mathrm{~cm}$ \\
\hline 9 & " & $\begin{array}{l}\text { silty sandstone } \\
\text { Astoria Formation. }\end{array}$ & $"$ & $5 \mathrm{ft}$ & 3.75 in & $9.5 \mathrm{~cm}$ \\
\hline 10 & $"$ & $"$ & $250 \mathrm{ft}$ & $"$ & 6.75 in & $17.1 \mathrm{~cm}$ \\
\hline 11 & $"$ & terrace sands & $"$ & $10 \mathrm{ft}$ & 18.0 in & $45.7 \mathrm{~cm}$ \\
\hline 12 & $"$ & $\begin{array}{l}\text { tuffaceous sandstone } \\
\text { Astoria Formation }\end{array}$ & $100 \mathrm{ft}$ & $"$ & $3.75 \mathrm{in}$ & $9.5 \mathrm{~cm}$ \\
\hline 13 & " & terrace sands & $150 \mathrm{ft}$ & $30 \mathrm{ft}$ & $4.0 \mathrm{in}$ & $10.2 \mathrm{~cm}$ \\
\hline 14 & 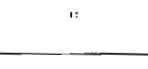 & $\begin{array}{l}\text { silty sandstone } \\
\text { Astoria Formation. }\end{array}$ & $130 \mathrm{ft}$ & $5 \mathrm{ft}$ & 6.0 in & $15.2 \mathrm{~cm}$ \\
\hline 15 & $"$ & $\begin{array}{l}\text { highly fractured sand- } \\
\text { stone, Astoria } \\
\text { Formation }\end{array}$ & $100 \mathrm{ft}$ & $3 \mathrm{ft}$ & 2.0 in & $5.1 \mathrm{~cm}$ \\
\hline 16 & " & $\begin{array}{l}\text { siltstone } \\
\text { Nye Formation }\end{array}$ & $300 \mathrm{ft}$ & $-6 \mathrm{ft}$ & $5.25 \mathrm{in}$ & $13.3 \mathrm{~cm}$ \\
\hline 17 & $"$ & terrace sands & " & $15 \mathrm{ft}$ & 6.25 in & $15.9 \mathrm{~cm}$ \\
\hline 18 & $"$ & $\begin{array}{l}\text { massive sandy silt- } \\
\text { stone, Nye Formation }\end{array}$ & " & $3 \mathrm{ft}$ & $9.25 \mathrm{in}$ & $23.5 \mathrm{~cm}$ \\
\hline 19 & $\begin{array}{l}\text { bench mark } \\
\text { stake }\end{array}$ & terrace sands & $300 \mathrm{ft}$ & $8 \mathrm{ft}$ & 3.50 in & $\begin{array}{r}8.9 \mathrm{~cm} \\
-\quad \\
\end{array}$ \\
\hline 20 & $" 1$ & $"$ & $"$ & $10 \mathrm{ft}$ & 6.25 in & $15.9 \mathrm{~cm}$ \\
\hline 21 & $"$ & $\begin{array}{l}\text { silty mudstone } \\
\text { Nye Formation }\end{array}$ & $"$ & $4 \mathrm{ft}$ & 4.75 in & $12.1 \mathrm{~cm}$ \\
\hline $2 \approx$ & $"$ & terrace sands & $350 \mathrm{ft}$ & $15 \mathrm{ft}$ & $18.75 \mathrm{in}$ & $47.6 \mathrm{~cm}$ \\
\hline 23 & $"$ & " & $"$ & $20 \mathrm{ft}$ & 18.00 in & $45.7 \mathrm{~cm}$ \\
\hline 24 & $"$ & $"$ & $200 \mathrm{ft}$ & $6 \mathrm{ft}$ & 4.0 in & $10.2 \mathrm{~cm}$ \\
\hline
\end{tabular}

